\title{
Use of Animal Venom Peptides/Toxins in Cancer Therapeutics
}

\author{
Ravi Kant Upadhyay* \\ Department of Zoology, D D U Gorakhpur University, India
}

Submission: March 27, 2018; Published: October 01, 2018

*Corresponding author: Ravi Kant Upadhyay, Department of Zoology, D D U Gorakhpur University, India, Email: rkupadhya@yahoo.com

\section{Abstract}

Animal venoms possess variety of toxins/proteins/peptides which act as ionic channel inhibitors and target vital physiological processes. Toxin peptides isolated from honey bee, wasp and scorpion show membrane binding, growth inhibition and strong cytolytic properties. These also inhibit angiogenesis and induce caspase-dependent apoptosis in melanoma cells through the intrinsic mitochondrial pathway protecting the experimental animals against tumor development. These toxin peptides exert cytotoxic effects on human oral cancer cells by inducting apoptosis via a p53-dependent intrinsic apoptotic pathway. These can be used as cancer therapeutic agents by loading them in liposomes. This lead to increase in their target specificity against cancer cells, shorten cell survival, and produce higher reactive oxygen species (ROS), and does enhancement in the number of apoptotic cells. In addition, toxins enhance G0/G1 enrichment upon treatment of cancer cells. Further, encapsulated honey bee, wasp and scorpion venoms exert much potent anti-cancer effect on many cancer cells lines.

Upon slight chemical modifications animal toxins could gear up higher selectivity, show much improved target specificity and lesser toxic effects because of charge optimization. After their improvement they show superiority over the conventional chemical drugs as an increase in net charge of the peptide, its hydrophobicity and anionicity and fluidity of the target cell membranes. It primarily imparts effect through biophysical interaction with the target cell membrane. Toxin peptides are best candidate as they selectively target malignant gliomas and play significant role in GBM immunotherapy. Venom toxins/peptides are good natural sources of compounds/molecules which could act as prototype or template which can be used for development of new therapeutic agents and best tools for diagnosis of not only for cancer but also for other diseases.

Keywords: Animal toxins peptides; Channel blockers; Anti-cancer effects; Drug delivery; Therapeutic applications

\section{Introduction}

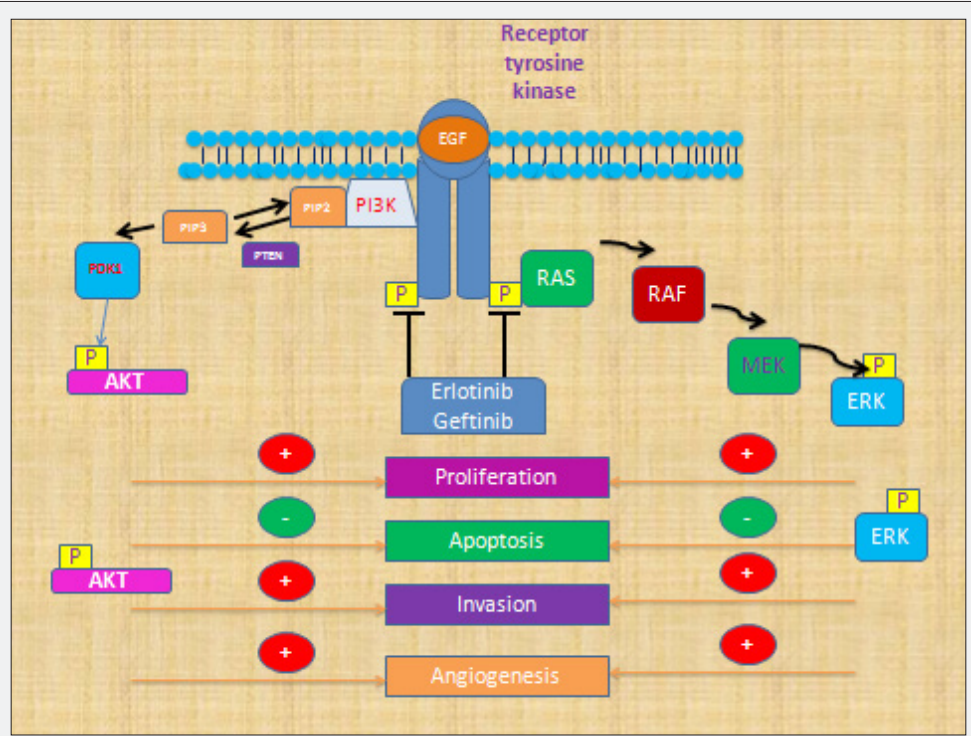

Figure 1: Showing various steps of cancer progression and its strong inhibition sites.

Cancer is a complex disease that shows abnormal cell growth with invasion of surrounding cells and tissues. Cancer is caused by a progressive accumulation of multiple genetic mutations which are evoked due to environmental stress, microbial infection, food adulteration, smoke, tobacco, ionizing radiation, heavy metal exposure, and multiple genetic reasons. Approximately 5-10\% 
of cancers are due to inherited genetic defects inherited from parents. Cancer is preventive if proper care and therapeutic dietary measures are maintained (Figure 1). Most cancer cells are derived from a single neoplastic cell possessing a regulatory defect, which is inherited by the clonal progeny. Unregulated growth in vivo: Cancer cells do not respond to normal regulatory mechanisms, they can proliferate indefinitely and show unregulated growth. Cancerous activity alters tissue-specific affinity that enables some cancer cells to grow beyond the boundaries of their tissue of origin. These cells can metastasize and grow in diverse tissue sites. Other cancer cells appear to acquire affinity for specific but "wrong" tissues; this property may account for the tendency of certain cancers to metastasize preferentially to particular tissue sites.

There are specific categories of oncogenes that inhibit cellular proliferation and regulate programmed cell death. Some tumors showed altered MHC expression and the wrong biological consequence regarding cell growth and cell proliferation. There are three important attacking points to control cancer invasion of tissues i.e. by activating tumor suppressor oncogenes, stop adhesion of cancer cells, growth and proliferation. Treatment of normal cultured cells with chemical carcinogens, irradiation, and certain viruses can alter the morphology and growth properties of the cells. In some case this process, referred to as transformation, makes the cells able to induce tumors when they are injected into animals; such cells are said to have undergone malignant transformation, and they often exhibit in vitro culture properties similar to those of cancer. They have decreased requirements for growth factors and serum, are no longer anchorage, dependent, grow in a density-independent fashion-and they are immortal.
The process of malignant transformation of cells could be used by using animal toxin peptides because they show cytotoxicity to cancer cells and work in a concert at several target sites and show wider therapeutic applications (Figure 1).

Animal venom is unique natural products synthesized by venoming animals. It is complex mixture of various toxins/ proteins, peptides, certain elements and acids. Animals inflict venom in self defense or to immobilize the prey for predation and digestion. Venom toxins cause multiple symptoms in stung animals and impart inhibitory effects on electrophysiology of ion channels. They act very fast and also cause respiratory paralysis or cardiac arrest in prey. There are wide varieties of natural toxins, i.e. neurotoxins, myotoxins, cardiotoxins, hematoxins and catalytic enzymes which act by diverse mechanisms on different cell types and cause multiple dysfunctions on the target cell cells, eventually leading to death of the prey [1].

The variety of proteins and peptides have been isolated from honey bee venom and wasp venom which include melittin, adiapin, apamine, bradykinin, cardiopep, mast cell degranulating peptide, mastoparan, phospholipase A2 and secapin. There are several venom proteins and peptides with possible therapeutic applications from bees and wasps and szcorpions. Some of these act very fast and target ion channels use as diagnostics and are therapeutically important [2]. Certain naturally occurring toxins from scorpion venom are used as molecular probes for investigating the potassium $\left(\mathrm{K}^{+}\right)$and calcium binding channels. Many of these toxins are selective for particular $\mathrm{K}^{+}$channel subtypes and gear a quick physiological effect on mammalian brain by attacking on cell membranes (Figure 2).

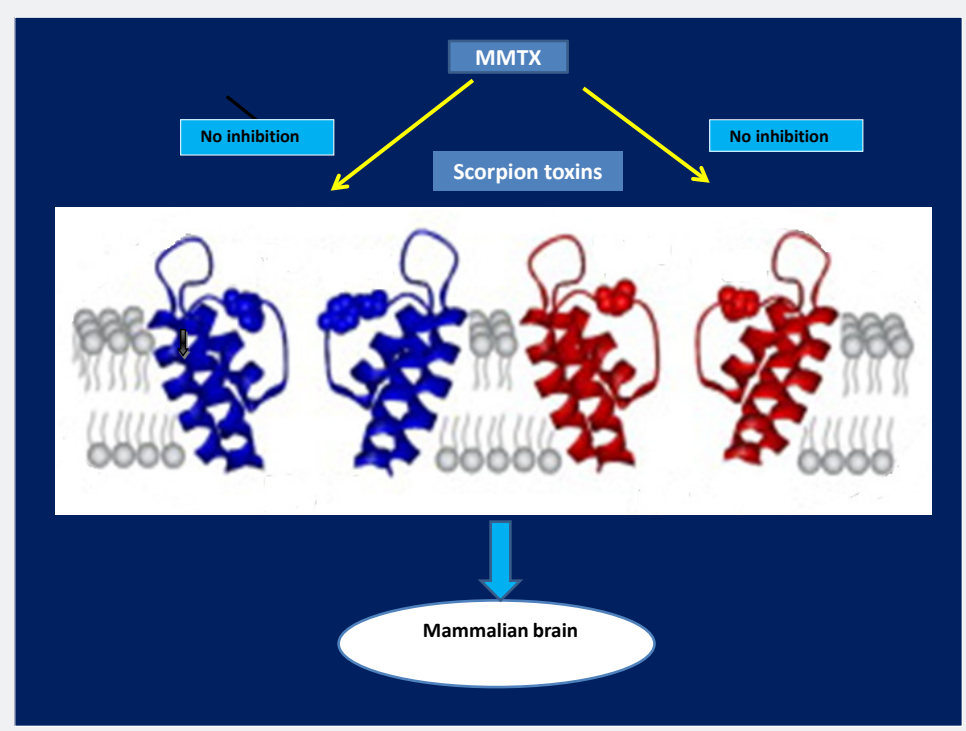

Figure 2: Showing action of scorpion neurotoxins on neuron membrane and its effect on mammalian brain.

Wasp venom is also a rich source of therapeutically important toxins which includes short cationic peptides, kinins and polyamines (Table 1). These are used in the treatment of pain, inflammatory disease, and neurodegenerative diseases such as epilepsy and aversion. Mastoparan is $\alpha$-helical and amphipathic cationic tetradecapeptide which is isolated from the venom of the wasp Vespula lewisii. It exhibits a wide variety of biological effect mainly tumor cell cytotoxicity and induce histamine release from mast cells. Mastoparan causes melanoma cell death by induction of caspase-dependent mitochondrial apoptosis pathway in murine 
model of B16F10-Nex2 cells. It shows cytolytic activity in tumor cells. Upon conjugation to poly (l-glutamic acid) PGA polymer through specific cleavage sequences it binds to over-expressed tumor proteases, such as the metalloproteinase-2 (MMP-2) or cathepsin $\mathrm{B}$ and become active.

Table 1: Showing Toxin Peptides Isolated from Different Animals, with their Physiological Effects and Therapeutic use.

\begin{tabular}{|c|c|c|c|c|}
\hline Animal & Name of Toxin Peptide & Physiological Effect & Toxin Category & Therapeutic use \\
\hline $\begin{array}{c}\text { wasp venom } \\
\text { Vespa, Parapolybia, } \\
\text { Protonectarina, Polistes } \\
\text { and Protopolybia. }\end{array}$ & Kinins and polyamines & Inflammation & Cytotoxic & $\begin{array}{l}\text { Anti-rheumatic dilates blood } \\
\text { vessels via the release of }\end{array}$ \\
\hline Wasp venom & Mastoparan & $\begin{array}{l}\text { Membrane-active amphipathic } \\
\text { peptide, it causes the secretion } \\
\text { of histamine from mast cells }\end{array}$ & $\begin{array}{l}\text { Cytotoxic, hemolytic } \\
\text { insert into the membrane } \\
\text { bilayer }\end{array}$ & $\begin{array}{c}\text { Anticancer effects and induce } \\
\text { caspase-dependent apoptosis } \\
\text { in melanoma cells, }\end{array}$ \\
\hline $\begin{array}{l}\text { Wasp and honey bee } \\
\text { venom }\end{array}$ & Melittin & $\begin{array}{l}\text { Severely acts upon motor } \\
\text { nerve terminals and muscle } \\
\text { cells }\end{array}$ & $\begin{array}{c}\text { Neuro and cytotoxic, } \\
\text { damages skeletal muscles } \\
\text { and inhibits cell regen- } \\
\text { eration }\end{array}$ & $\begin{array}{l}\text { Melittin displays anti-prolif- } \\
\text { erative activity to cancer cells } \\
\text { in vivo }\end{array}$ \\
\hline Wasp venom & Bradykinin & $\begin{array}{l}\text { Impose inflammatory reac- } \\
\text { tions, bradykinin elevate vas- } \\
\text { cular permeability and cause } \\
\text { vasodilatation in some arteries } \\
\text { and vein }\end{array}$ & $\begin{array}{l}\text { Show biological effects } \\
\text { via G protein - coupled } \\
\text { receptors. }\end{array}$ & $\begin{array}{l}\text { Antimicrobial and anticancer } \\
\text { agents }\end{array}$ \\
\hline $\begin{array}{l}\text { Honey bee venom and } \\
\text { wasp venom }\end{array}$ & Adiapin, apamine & Polycationic peptides & $\begin{array}{l}\text { Antimicrobial and anti- } \\
\text { cancer agents }\end{array}$ & $\begin{array}{l}\text { Activities against other } \\
\text { gram-negative bacteria } \\
\text { and Gram-positive }\end{array}$ \\
\hline $\begin{array}{l}\text { Wasp and honey bee } \\
\text { venom }\end{array}$ & Cardiopep & Polycationic peptides & $\begin{array}{l}\text { Antimicrobial and anti- } \\
\text { cancer agents }\end{array}$ & $\begin{array}{l}\text { Hyperalgesic and } \\
\text { edematogenic }\end{array}$ \\
\hline $\begin{array}{l}\text { Wasp and honey bee } \\
\text { venom }\end{array}$ & $\begin{array}{l}\text { Mast cell degranulating } \\
\text { peptide }\end{array}$ & Polycationic peptides & Activation of $\mathrm{G}$ protein & $\begin{array}{c}\text { Antimicrobial and anticancer } \\
\text { agents }\end{array}$ \\
\hline $\begin{array}{l}\text { Wasp and honey bee } \\
\text { venom }\end{array}$ & Phospholipase A2 & Polycationic peptides & Cytotoxic & $\begin{array}{c}\text { Antimicrobial and anticancer } \\
\text { agents }\end{array}$ \\
\hline $\begin{array}{l}\text { Wasp and honey bee } \\
\text { venom }\end{array}$ & secapin & $\begin{array}{l}\text { Africanized honeybee (Apis } \\
\text { mellifera) venom }\end{array}$ & $\begin{array}{l}\text { Induces inflammation } \\
\text { and pain }\end{array}$ & $\begin{array}{l}\text { Potent dose-related hyper- } \\
\text { algesic and edematogenic } \\
\text { responses }\end{array}$ \\
\hline Wasp Agelaia pallipes & Protonectin & $\begin{array}{l}\text { Promotes mast cell degranula- } \\
\text { tion activity, antibiosis against } \\
\text { Gram-positive and -negative } \\
\text { bacteria, }\end{array}$ & $\begin{array}{l}\text { peptide isolated from the } \\
\text { venom of the, and chemo- } \\
\text { taxis in polymorphonu- } \\
\text { cleated leukocytes }\end{array}$ & $\begin{array}{c}\text { Antitumor effects, nhibit the } \\
\text { growth of both bacteria and } \\
\text { fungi }\end{array}$ \\
\hline $\begin{array}{l}\text { Wasp and honey bee } \\
\text { venom }\end{array}$ & PLA2 & $\begin{array}{l}\text { Acts synergistically, breaking } \\
\text { up membranes of susceptible } \\
\text { cells and enhancing their } \\
\text { cytotoxic effect }\end{array}$ & Cytotoxic & $\begin{array}{l}\text { PLA2 as a novel anticancer } \\
\text { conjugate, hydrolyse the } \\
\text { membrane of various cells. }\end{array}$ \\
\hline $\begin{array}{l}\text { Wasp and honey bee } \\
\text { venom }\end{array}$ & $\begin{array}{l}\text { Anoplin (GLLKRIK- } \\
\text { TLL-NH2) }\end{array}$ & $\begin{array}{l}\text { Candidate because of its small } \\
\text { size as well as its antimicrobial } \\
\text { and nonhemolytic properties }\end{array}$ & $\begin{array}{l}\text { Cytotoxicity in Friend } \\
\text { virus-induced leukemia } \\
\text { cells murine erythroleu- } \\
\text { kemia }\end{array}$ & $\begin{array}{l}\text { Novel and selective antican- } \\
\text { cer agent. }\end{array}$ \\
\hline $\begin{array}{l}\text { Wasp and honey bee } \\
\text { venom }\end{array}$ & Acyl Polymaines & $\begin{array}{c}\text { Non-competitive inhibition at } \\
\text { glutatamete receptors, leading } \\
\text { to paarlysis }\end{array}$ & Neurotoxic & $\begin{array}{c}\text { Exhaustive release of neuro- } \\
\text { modulatprs at nerve endings } \\
\text { cause }\end{array}$ \\
\hline Polibia polista & $\begin{array}{l}\text { Phosphilase, hyluroni- } \\
\text { dasesmastoparans }\end{array}$ & $\begin{array}{c}\text { Genotoxic, mutagenic and } \\
\text { damages in the genetic ma- } \\
\text { terial }\end{array}$ & $\begin{array}{l}\text { Cytotoxic, hemolytic } \\
\text { activit, exhibit potent } \\
\text { anticancer activity }\end{array}$ & $\begin{array}{l}\text { Broad spectrum antibacteri- } \\
\text { al, and human glioblastoma } \\
\text { multiforme cells }\end{array}$ \\
\hline Polibia polista & $\begin{array}{c}\text { Cationic peptides (Polibia } \\
\text { MP-I) }\end{array}$ & Antifungal activity & Cytotoxic & $\begin{array}{l}\text { Exhibit potent anticancer } \\
\text { activity toward human glio- } \\
\text { blastoma multiforme cells }\end{array}$ \\
\hline Vespa tropica & Chemotactic peptides & $\begin{array}{l}\text { Antimicrobial activity activate } \\
\text { cell mediated antiviral immune } \\
\text { response }\end{array}$ & Cytotoxic & Anticancer agent \\
\hline
\end{tabular}




\section{Current Trends in Biomedical Engineering \& Biosciences}

\begin{tabular}{|c|c|c|c|c|}
\hline Vespa flavitarsus & Hornetin protein & $\begin{array}{l}\text { Hemolytic activity in RBCs and } \\
\text { presynaptic neurotoxicity }\end{array}$ & $\begin{array}{l}\text { Neurotoxicity, antimicro- } \\
\text { bial, anticancer agents }\end{array}$ & $\begin{array}{l}\text { Treatment of pain, inflamma- } \\
\text { tory disease, and neurode- } \\
\text { generative diseases such as } \\
\text { epilepsy and aversion. }\end{array}$ \\
\hline Polibia scutellaris & Hypoallergic variants & $\begin{array}{c}\text { Antigen } 5 \text { allergen, hypoaller- } \\
\text { gic variants }\end{array}$ & Cytotoxic & Allergic \\
\hline Nasonia vitripensis & Polistine peptides, & $\begin{array}{l}\text { Reduce thiol group of cystine } \\
\text { residue do not form disulphide } \\
\text { bridge, }\end{array}$ & Cytotoxic & $\begin{array}{l}\text { Promote programmed cell } \\
\text { death, elicited detoxifica- } \\
\text { tion responses and induced } \\
\text { immune responses }\end{array}$ \\
\hline Agelaia pallipes & Cationic peptide & $\begin{array}{l}\text { Inhibits the growth of gram } \\
\text { positive and gram-negative } \\
\text { bacteria }\end{array}$ & Cytotoxic & $\begin{array}{l}\text { Antimicrobial activities, } \\
\text { anti-tumors drugs }\end{array}$ \\
\hline Vespa orientalis & Crude venom & $\begin{array}{c}\text { Inhibits the growth of gram }(+) \\
\text { and gram (-) bacterial cells }\end{array}$ & Cytotoxic & Anticancer agent \\
\hline Vespa affinis & Allergic proteins & $\begin{array}{l}\text { Local reaction, IgE mediated } \\
\text { anaphylaxis, systemic reaction }\end{array}$ & Cytotoxic & Anticancer agent \\
\hline Polibia paulista & Common peptides & $\begin{array}{l}\text { Defensive tools to protect the } \\
\text { colonies of insects against } \\
\text { attacks of the predators. }\end{array}$ & Neurotoxic & Anticancer agent \\
\hline Vespa crabo (L) & Crude venom peptides & Local reaction & Allergic & Anticancer agent \\
\hline Vespa vetulina & $\begin{array}{l}\text { Hemostasis-imparing } \\
\text { toxins }\end{array}$ & Allergic and toxic effects & Cytotoxic & Anticancer agent \\
\hline Nasonia vitripensis & Steroids, cytokine IL-1 $\beta$ & $\begin{array}{l}\text { Alters the expression of some } \\
\text { drug targets,NF-k } \boldsymbol{\beta} \text { pathway }\end{array}$ & Cytotoxic & Anticancer agent \\
\hline Anopolis samariensis & $\begin{array}{l}\text { Alpha-PMTX-13 amino } \\
\text { acid peptides }\end{array}$ & $\begin{array}{l}\text { Both excitatory or inhibitory } \\
\text { synaptic transmission }\end{array}$ & Neurotoxic & Anticancer agent \\
\hline Vespa vulgaris & $\begin{array}{l}\text { Phospolipase A, hyluroni- } \\
\text { dase A, and antigen } 5\end{array}$ & $\begin{array}{l}\text { Severe local swelling accompa- } \\
\text { nied by fever }\end{array}$ & Cytotoxic & Anticancer agent \\
\hline Vespa germanica & $\begin{array}{l}\text { Phospolipase A, hyluroni- } \\
\text { dase A, and antigen } 5\end{array}$ & $\begin{array}{l}\text { Severe local swelling accompa- } \\
\text { nied by fever }\end{array}$ & Cytotoxic & Anticancer agent \\
\hline Chelonus inanitis & $\begin{array}{l}\text { Potentially lineage-specific } \\
\text { protein (hyluronidases and } \\
\text { allergen 5) }\end{array}$ & $\begin{array}{l}\text { Parasitoids from encapsulation } \\
\text { by hosts nutritional physiology } \\
\text { and induce a developmental } \\
\text { arrest in pre-pupal stage. }\end{array}$ & Cytotoxic & Anticancer agent \\
\hline Agelaia pallipes & $\begin{array}{l}\text { Cationic peptides, anti- } \\
\text { microbial peptides-crude } \\
\text { venom }\end{array}$ & $\begin{array}{l}\text { Antimicrobial inhibits the } \\
\text { growth of gram positive and } \\
\text { gram-negative bacterial cells. }\end{array}$ & Cytotoxic & Antitumor activity \\
\hline $\begin{array}{l}\text { wasp and honey bee } \\
\text { venom }\end{array}$ & Polybia-MPI & $\begin{array}{c}\text { selectively inhibit the prolifer- } \\
\text { ation of prostate and bladder } \\
\text { cancer cell }\end{array}$ & $\begin{array}{l}\text { shows good antitumor } \\
\text { activity }\end{array}$ & \\
\hline $\begin{array}{l}\text { Sea snail Conus geogra- } \\
\text { phus }\end{array}$ & $\mu-$ Conotoxin $(\mu-\mathrm{CTX})$ & $\begin{array}{l}\text { Specifically target voltage-gat- } \\
\text { ed sodium channels. }\end{array}$ & $\begin{array}{l}\text { Receptor site } / \mathrm{Na}^{+} \text {chan- } \\
\text { nel blocker }\end{array}$ & $\begin{array}{l}\text { Propagate electrical signals in } \\
\text { muscles and nerves }\end{array}$ \\
\hline sea anemone toxins & ASVI, AX I, AX II and AS II. & $\begin{array}{l}\text { AS II is one of the most abun- } \\
\text { dant sea anemone toxins }\end{array}$ & $\begin{array}{l}\text { works on mammalian } \mathrm{Na}^{+} \\
\text {channels }\end{array}$ & Anticancer \\
\hline Haplopelma hainanum & Hainantoxin IV & $\begin{array}{l}\text { Inhibit tetrodotoxin -sensitive } \\
\text { voltage-gated sodium chan- } \\
\text { nels, thereby causing blockage } \\
\text { of neuromuscular transmis- } \\
\text { sion and paralysis }\end{array}$ & $\begin{array}{l}\text { Neurotoxins from the } \\
\text { venom of the Chinese } \\
\text { bird spider binds to sodi- } \\
\text { um channels, block and } \\
\text { inactivate them }\end{array}$ & Anticancer \\
\hline Spider & Jingzhaotoxin-I & Neurotoxin & $\begin{array}{l}\text { Preferentially inhibits } \\
\text { cardiac function in rat. }\end{array}$ & $\begin{array}{l}\text { Exhibit better anti-cancer } \\
\text { efficacy on the colorectal } \\
\text { cancer cell line }\end{array}$ \\
\hline $\begin{array}{c}\text { North African scorpion, } \\
\text { Androctonus australis } \\
\text { Hector }\end{array}$ & $\begin{array}{l}\text { Lqh2 and Lqh } \alpha \text { II } \\
\text { AaHTH4 has }\end{array}$ & $\begin{array}{l}\alpha \text {-insect, antimammalian, and } \\
\text { bind to voltage-gated sodium } \\
\text { channels and slow down chan- } \\
\text { nel inactivation }\end{array}$ & $\alpha$ neurotoxins & Anticancer \\
\hline
\end{tabular}


Current Trends in Biomedical Engineering \& Biosciences

\begin{tabular}{|c|c|c|c|c|}
\hline $\begin{array}{c}\text { Androctonus bicolor } \\
\text { (AB), }\end{array}$ & $\begin{array}{c}\text { AahI-AahI'-AahII: Toxins of } \\
\text { Aah Venom }\end{array}$ & $\begin{array}{c}\text { Induces cell cycle arrest and } \\
\text { apoptosis }\end{array}$ & Exhibits cytotoxicity & Anticancer property \\
\hline $\begin{array}{c}\text { Leiurus quinquestriatus } \\
\text { (LQ) }\end{array}$ & Lqh & Cytotoxic and apoptotic effects & $\begin{array}{c}\text { Stimulation of cardiac } \\
\text { effects }\end{array}$ & $\begin{array}{c}\text { Toxin acts at the membrane } \\
\text { level anticancer }\end{array}$ \\
\hline scorpion venom & Chlorotoxin (CTX) peptide & $\begin{array}{c}\text { Selectively blocks glioma Cl(-) } \\
\text { channel activity }\end{array}$ & Target malignant gliomas. & Cytotoxic \\
\hline
\end{tabular}

As it is established fact that toxins/peptides from animal venom typically target ion channels and receptors of both the central and peripheral nervous system, interfering with action potential conduction and/or synaptic transmission. These peptides showed very high degree of sequence homology/ conservation of their molecular targets, which makes these toxins active at human receptors. The high selectivity and potency displayed by some of these toxins could be used as pharmacological tools as well as diagnostic probes for detection of morbidity. In present review article important biological effects of toxins, their hydrophobic and ionic interactions, voltage gated channel binding and receptor interactions in cell membranes have been explained. Though animal venom toxins from wasp, bees and scorpion act as potential therapeutic agents and display profound anticancer effects but partial modification in their structure could increase their anticancer potential. These modifications are possible in hydrophobicity, surface charges, and amino acid substitutions in active site regions, topological folding, hydrophobic pockets and binding affinity. For this purpose, modifications like site-specific mutations and gene rearrangements could provide more active recombinant toxin peptides that will show much cytolytic activity and any drug.

Few antigenic shifts in toxins cold remove their toxicity against normal animal cells and might behave as cell-penetrating peptide that will affect cancer cell proliferation, migration, invasion, apoptotic activity and neo-vascularization. It also highlighted miRNA-based therapeutics, with possible directions for improvement in target specificity of toxins when to be used as a complete therapeutic tool against tumor and cancer. Because of their high selectivity, these toxins can be employed as pharmacological tools in disease diagnosis and therapeutic interventions for gliomas (Figure 3). This article also highlighted encapsulation and conjugation of toxins with onconase, drugs, and lipids to develop new highly efficacious therapeutic delivery system.

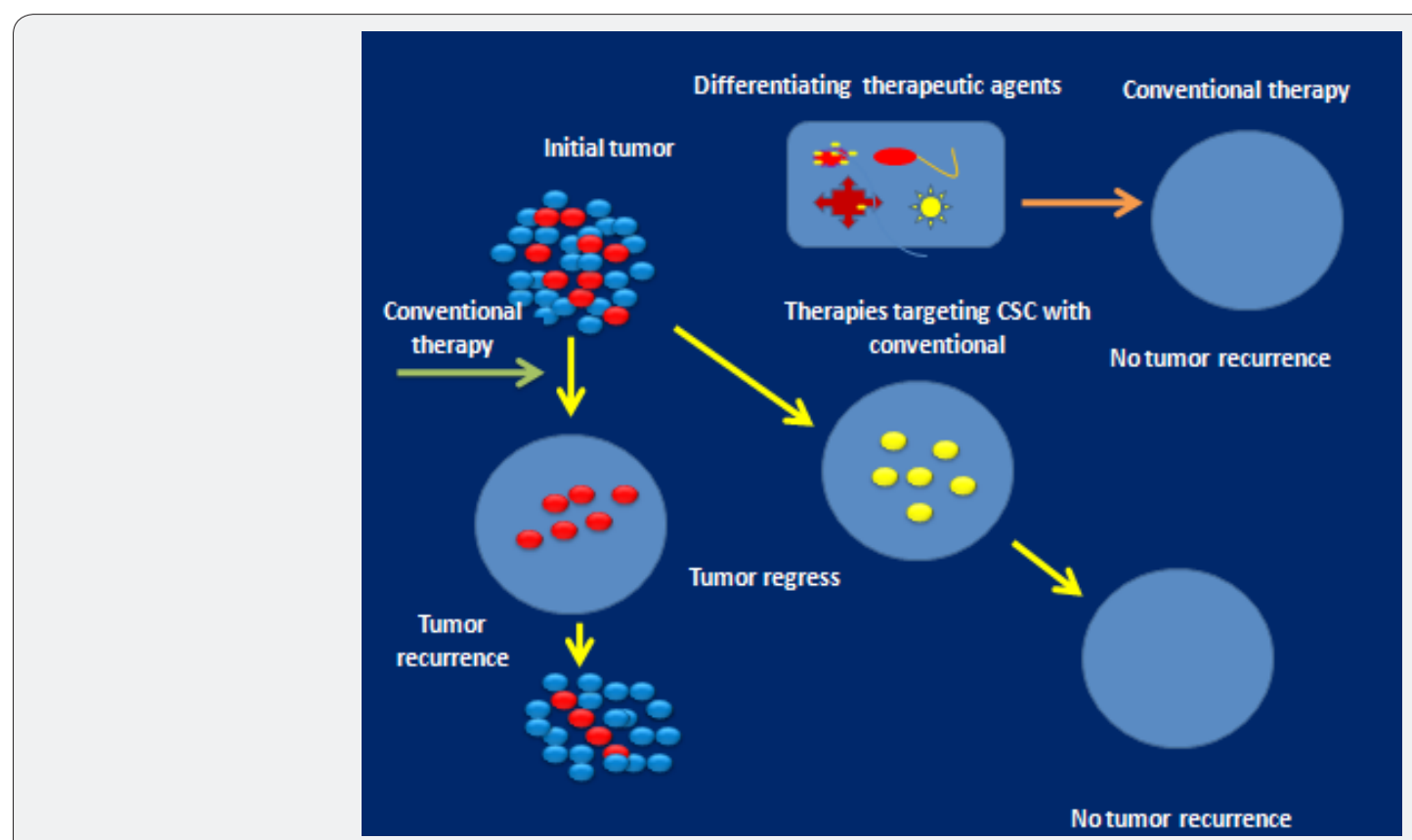

Figure 3: Showing use of conventional therapy and toxin related therapeutic agents.

\section{Mode of Action}

The mode of action of animal toxins and their physiological consequences vary greatly according to the structural variability in the active site region of toxins. Physiologically animal toxins block ion various channels and breach the normal barrier to free the movement of molecules across cell membrane. Besides this, some toxins are enzymatic in nature and hydrolyze membrane phospholipids and form channels through which small molecules may pass. Melletin of bee venom is an example of such type of toxin. Few toxins cause enormous hemolysis of RBCs and damage nerve cells. Venom toxins specifically act upon neurons, nicotinic acetylcholine receptors and neuromuscular junctions.

A phospholipase toxin severely acts upon motor nerve terminals and muscle cells. It damages skeletal muscles and 
inhibits cell regeneration. Different animal groups have different channel inhibitors. Some toxins are inhibitors of metabolic enzymes and have hydrophobic pockets in their secondary structure by which they bind at specific substrate binding sites. Protease inhibitors found in animal venom bind to protease enzymes and prevent their activity. These also inhibit fibrin activity in arthritic joints and induce chronic arthritis in patients. Besides this, venom toxins induce important pathological effects such as immune-modulatory, cardio-respiratory, analgesic and hemopoeitic in experimental animals. Moreover, venom factors also cause acute and chronic inflammatory responses in laboratory animals. Histamine inhibits vaso-dilation in mast cells of lungs, liver and gastric mucosa with allergic hyper-sensitivity and inflammation. More specifically citrate present in arthropod venom inhibits phospholipase A2 activity [3].

After few seconds of envenomation toxins cause sudden inflammation in body cells with a severe pain and do massive inhibition of axonal transmission in neurons. Toxins also affect activity of ATP driven $\mathrm{Na}^{+}-\mathrm{K}^{+}$ATPase pump, which plays a key role in maintaining cell volume and intra cellular ionic composition specially $\mathrm{Na}^{+}$and $\mathrm{K}^{+}$gradients. This pump actively transports ions across the cell membrane and also helps in excitation of nerves and does phosphorylation and de-phosphorylation in muscle cells. In this mechanism some trans-membrane proteins/ enzymes utilize the energy stored in molecules of ATP to move $\mathrm{K}^{+}$into the neuron. $\mathrm{Na}^{+}-\mathrm{K}^{+}$pump helps the neurons to maintain resting potential for which pump allows interior negative charge and exterior positive charge on neurons by pumping $\mathrm{Na}^{+}$outside the cell and $\mathrm{K}^{+}$inside the cell (Figure 4). Both $\mathrm{Na}^{+}$and $\mathrm{K}^{+}$channels are competitively blocked by these toxins and induce the release of transmitters and cause repetitive firing of the axons (Table 2). Toxins also change the orientation and affinity of ion binding sites change ion permeability mediated by the nicotinic Ach receptors. Snake, neurotoxins such as $\alpha$-bungarotoxin and cobra toxin block neuromuscular transmission, affect sodium and calcium exchanges and block ion channels forming a tight ring [4].

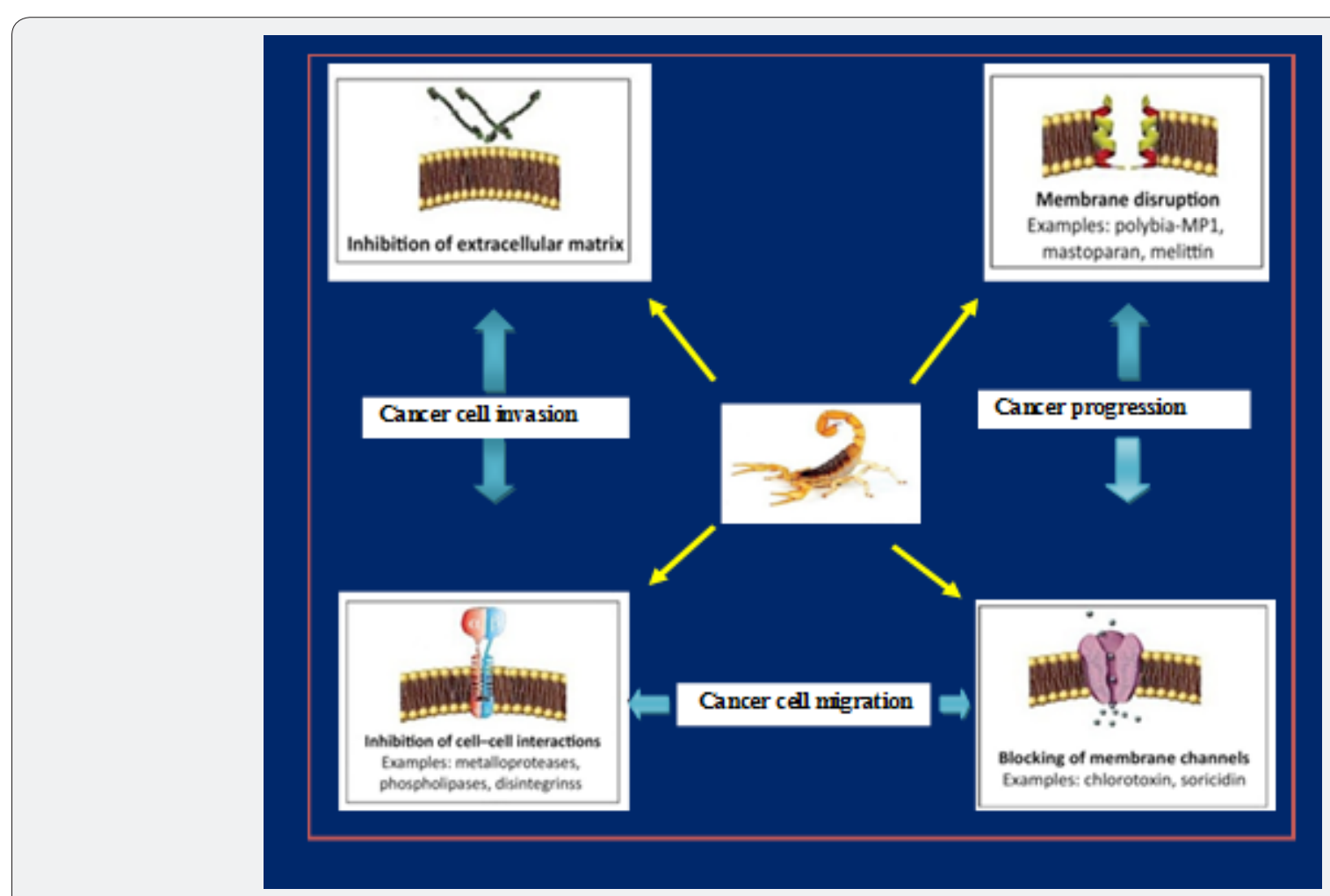

Figure 4: Shows interaction of scorpion venom toxins to membrane its various phases of disruption.

The toxicity of venom toxins depend upon the sequence of the amino acid residues present in the active site regions, topological folding, hydrophobic pockets and binding affinity. Basically modifications like site-specific mutations and rearrangements occurred in the active site region in response to gradual environmental changes in due course of time have resulted in structural and functional diversifications of toxins. Therefore, different biologically active toxins have been evolved even within a single animal species. However, most of the toxins are identified as neurotoxic, which block various types of ion channels. Different animal groups produce different toxins but each of them shows significant evolutionary relationship in structure especially in their active site regions.

\section{$\mathrm{Na}^{+}$Channel Inhibitors}

Voltage gated $\mathrm{Na}^{+}$channels are the key elements of signal transduction in membranes of excitable cells. These voltage-gated channels are transmembrane proteins responsible for rising phase of action potential in most excitable cells (Figure 1). These channels get rapidly activate and inactivate upon depolarization of cell membrane, which result in transient and selective increase in $\mathrm{Na}^{+}$conductance. Besides this, $\mathrm{Na}^{+}$channels are the targets of 
the several kinds of neurotoxins [5] including scorpion toxins. Buthidae family of scorpion contains two major classes - $\alpha$ - and $\beta$ toxins among which, Lqh2 and Lqh $\alpha$ II are the $\alpha$ neurotoxins that are toxic to mammals and insects respectively [6]. These toxins are the modifiers of the voltage sensitive $\mathrm{Na}^{+}$channels. Lqh $\alpha$ II is an efficient bacterial expression system of a scorpion $\alpha$ - neurotoxin with exceptionally high insecticidal activity [7]. Lqh $\alpha$ II slows the $\mathrm{Na}^{+}$current inactivation in excitable membrane in a manner

Table 2: Important $\mathrm{Na}^{+}, \mathrm{K}^{+}$and $\mathrm{Cl}^{-}$channel inhibitors in animals.

Table 2A: $\mathrm{Na}^{+}$Channel Inhibitor.

\begin{tabular}{|c|c|c|}
\hline Name of Toxin & Name of Species & Effect \\
\hline$\mu$-Conotoxin & Conus geographus & Blocks cardiac and skeletal muscle \\
\hline Toxin I \& П (AT X I \& П) & Anthopleura xanthogramica & Do \\
\hline veratridine (APB) & Anemone sulcata & Do \\
\hline Tetradotoxin & Tetraodon cutcutia & Acts on human cardiac muscle \\
\hline $\begin{array}{l}\text { Anti-insect Toxin (AaH1 } \\
\text { T4) }\end{array}$ & $\begin{array}{l}\text { Androctonus australis (Hec- } \\
\text { tor) }\end{array}$ & Acts on $\alpha$ and $\beta$ sets of mammalian $\mathrm{Na}^{+}$Channel \\
\hline Chrotamint & Crotalus durissus & Local myonecrosis \\
\hline TSII & Tityus serrulatus (Scorpian) & Induce convulsion in rat \\
\hline BMKMI & E. coli & Paralysis of rear leg, Loss of balance, respiratory death \\
\hline AaHTH4 & Androctonus australis & $\begin{array}{c}\text { Acts on insects } \mathrm{Na}^{+} \text {channel as well as on } \alpha \text { and } \beta \text { type of the mammalian Sodium } \\
\text { channels }\end{array}$ \\
\hline Bg П / Bg III & Bunodosoma granulifera & Prolong action potential \\
\hline Caliotoxin & Calliactis parasitica & Neurotoxic, $\mathrm{Na}^{+}$Channel blocker \\
\hline
\end{tabular}

$\mu$ - Conotoxin $(\mu-\mathrm{CTX})$ is a receptor site $/ \mathrm{Na}^{+}$channel blocker isolated from sea snail Conus geographus that specifically inhibit $\mathrm{Na}^{+}$flux in skeletal muscles and eel $\mathrm{Na}^{+}$channels with high affinity by physically occluding the channel pores. $\mu$ - CTX also blocks cardiac and brain $\mathrm{Na}^{+}$channel. $\mu$ - CTX is a peptide consisting of 22 amino acid residues with six cysteins, which form three disulphide bridges. This toxin blocks cardiac and nerve cell activity. Voltage gated $\mathrm{Na}^{+}$channels are composed of a pore forming $\alpha$ subunit (26 KDa) and 1-3 auxiliary $\beta$ subunits (Table 2). The $\beta 2$ subunit (21 KDa) is disulphide linked to $\alpha$ subunit while $\beta$ I (23KDa) subunits are non-covalently attached. $\mu$-conotoxins do potential inhibition of tetradotoxin-sensitive voltage gated sodium channels [9]. Delta conotoxin isolated from Conus ermineus selectively act upon vertebrate neuronal $\mathrm{Na}+$ channels [10]. $\mu$-conotoxin ( $\mu$ CTX) isolated from snail Conus geographus specially inhibit $\mathrm{Na}^{+}$flux in skeletal muscles and bind to $\mathrm{Na}^{+}$channel with high affinity binding to block the channel pore. $\mu$ - cono toxin specifically occludes the pore of voltage dependent $\mathrm{Na}^{+}$channel [11]. $\mu$-CTX is peptides consisting of 22 amino acids residues with six cysteines that form three internal disulphide bonds, impart extreme rigidity to the toxin molecule [12].

Tetrodotoxin is a highly potent poison that is isolated from puffer fish. It (TTX) blocks the conduction of nerve impulses along axons and in excitable membrane of nerve fibres, which lead to respiratory paralysis. Tetrodotoxins are insensitive (TTX-I) to voltage dependent $\mathrm{Na}^{+}$channels and are critical for initial rapid characteristic of other $\alpha$ - toxins [8]. A new anti insect AaHTH4 has been isolated from the venom of North African scorpion, Androctonus australis Hector (Table 2A). A similar toxin BMKM 1 is isolated from E. coli, which causes paralysis of rear legs, loss of balance, respiratory abnormality, incontinence and eventually death in insects (Table 2A). Different toxin/s groups showed distinct electrophysiological properties, but most of them bind to a common site on the $\mathrm{Na}^{+}$channels of insect. upstroke of the cardiac action potential and are responsible for most of the $\mathrm{Na}^{+}$current that occurs in mammalian heart. Similarly protein kinase $\mathrm{C}$ acts as inhibitor of tetrodotoxin-resistant $\mathrm{Na}+$ channels in small dorsal root ganglion and sensory neurons in rats [13]. Besides this, sea anemone toxins interact with large variety of excitable membranes including myelinated and non-myelinated axons. There exist four sea anemone toxins namely ASVI, AX I, AX II and AS II. Among which AS II is one of the most abundant sea anemone toxin that works on mammalian $\mathrm{Na}^{+}$channels. Sea anemones produce cardio and neurotoxins, which mainly cause inactivation of $\mathrm{Na}^{+}$channels, slow down sodium permeability and do prolongation of action potential. In nerve, cardiac and skeletal muscle cell in culture animal toxins effectively inhibit transmission and do make failure of contraction and excitation. Besides these, Bg II and Bg III toxins have been purified and sequenced from the Sea anemone Bunodosoma granulifera. BgII specially affect the insect $\mathrm{Na}^{+}$channel (Table 1). Both Bg II and Bg III cause the inactivation of voltage gated $\mathrm{Na}^{+}$channels [14]. ATXII from Anemonia sulcata and Ap B from Anthopleura xanthogrammica inhibit the inactivation process of $\mathrm{Na}^{+}$channel but shows cardiotoxic and neurotoxic effects.

Similarly Jingzhaotoxin-I a novel spider neurotoxin preferentially inhibits cardiac function in rat [15], target voltage gated sodium channels and inactivate them [16]. Besides this, few paralyzing peptides have been isolated from sea anemone Bunodosoma caissaum [17] and Phoneutria nigreventer. These are identified as neuronal sodium, channel inhibitor and interact 
with micro-conotoxin binding sites [18]. Similarly a neurotoxic lipopeptide kalkitoxin interacts with voltage sensitive sodium channels in cerebral granule neurons [19]. Similarly an alpha like scorpion neurotoxin BmK I play an important role in voltage gated $\mathrm{Na}+$ channels in excitation-contraction coupling of heart rate [20]. Besides this, hainantoxin IV binds to sodium channels, block and inactivate those [21] (Table 2).

Similarly delta-atracotoxin target the voltage gated sodium channels [22]. This polypeptide has a toxic effect on insects and mammals and is capable of competing with anti-insect scorpion toxins for binding to the $\mathrm{Na}^{+}$channels of insects. It also modulates the binding of alpha and bita type anti -mammal scorpion toxin to the sodium channels [23]. This toxin shows biological activity only in insects and cause contractional paralysis in them. Electrophysiological and binding studies showed that pharmacological target of anti mammal toxin is the voltage dependent $\mathrm{Na}^{+}$channels of excitable cell [24]. Similarly, effects are also noted after inflction of saxitoxin (STX), produced by a marine dinoflagellate. Physiologically TTX (tetrodotoxin), STX (Saxitoxin), and $\mu$-conotoxin block $\mathrm{Na}^{+}$channels from different tissues with vastly different affinities (Table 2). In contrast brain and skeletal muscle channels show a different magnitude of binding and are more sensitive to TTX and STX than are heart channels found in heart muscles [25].

\section{$\mathrm{K}^{+}$Channels Inhibitors}

Potassium channels occur in almost all living organisms and form potassium selective pores which span cell membranes [26]. Due to their high ionic interaction they control a wide variety of cell functions. There is a family of $\mathrm{K}^{+}$channel inhibitors that includes charybdotoxin, noxiustoxins, kaliotoxins and iberiotoxins. Among these some are voltage-gated channels and some are pure ionic channels. All these channel inhibitors are short peptides of 2835 amino acids in length and show different toxicity in different animals. Few scorpion toxins are $\mathrm{K}^{+}$channel inhibitors, which bind to a receptor site at the cell membrane or extra cellular vestibule and prevent conduction of cellular fluid and ion across the membrane. These toxins also variably affect the activity of ventricular myocytes in rat. Iberiotoxin is a small globular polypeptide isolated from Buthus tamulus, which shows high potential when added to extracellular fluid $[27,28]$. The same activity has also shown by TSTX -K isolated from Tityus serrulatus [29]. Besides these, there are some low conductance $\mathrm{Ca}^{+}$activated $\mathrm{K}^{+}$channels, which show mild toxicity. In this category P05, a polypeptide and apamin, a bee toxin shows similar physiological properties and block $\mathrm{K}^{+}$channels. Bmpo 2 is a 28 amino acid residues peptide purified from the venom of the Chinese scorpion Buthus mortensi Karsh, which shows very low inhibition of apamine sensitive calcium activated potassium channel [30]. Bgk toxin isolated from sea anemone blocks membrane potential and suppresses $\mathrm{K}^{+}$current in rat neurons [31] (Table 2B). Another toxin Shk from sea anemone inhibits $\mathrm{K}^{+}$ channels in T-lymphocytes in very low concentration [32] (Table 2).

Charybdotoxin (ChTX) and naxiustoxin bind to an extra cellular receptor site and prevent ion conduction by occluding the pore. Both toxin bind by a pore binding mechanism established high conductance of $\mathrm{Ca}^{+}$activated $\mathrm{K}^{+}$channels. It is formed due to presence of similar amino acid sequences especially in active site region [33]. Single amino acid modifications in toxin binding region can either increase or decrease the affinity of a given toxin for a specific channel.ChTX, agiotoxin (AgTX) and kaliotoxin (KTX) are the potent inhibitors of the shaker $\mathrm{K}^{+}$channels $(\mathrm{Kd}<1 \mathrm{nM})$ (Table 2B). A $\mathrm{K}^{+}$channel inhibitor containing 37 amino acid residues from the sea anemone Bunodosoma granuifera (BgK toxin) shows an apparent Ki of $0.7 \mathrm{nM}$ and suppresses $\mathrm{K}^{+}$current in rat dorsal ganglion, while ShK toxin isolated from the sea anemone Stichodactyla helianthus, shows an apparent Ki value of $0.7 \mathrm{nM}$ for inhibition. Thus ShK toxin also blocks Kv 1.3 type $\mathrm{K}^{+}$channels in Jukrat T- lymphocytes at very low concentration. Similarly a new conotoxin superfamily has been identified which act upon $\mathrm{K}^{+}$channels [34] and induce confirmation changes in potassium channels [35] (Table 2).

Table 2B: $\mathrm{K}^{+}$Channel Inhibitors.

\begin{tabular}{|c|c|c|}
\hline Name of Toxin & Name of Species & Effect \\
\hline BTK -2 & Buthus tamulus & Inhibitor of $\mathrm{K}^{+}$channel \\
\hline Arthropod venom & Apis mellifera & Phospholipase A2 \\
\hline BmBKTx1 & Buthus martensi & $\mathrm{K}^{+}$blocker \\
\hline Sq KVIA & Tityus serruiatus & $\mathrm{K}^{+}$channel blocker \\
\hline ChTX & Buthus mortensi & $\begin{array}{l}\text { Bind to a receptor site in the extra Cellular vestibule and } \\
\text { prevention ion Conduction by occluding the pore }\end{array}$ \\
\hline BmTX I & Buthus mortensi & Block high conductance $\mathrm{Ca}^{+}$activated $\mathrm{K}^{+}$channel \\
\hline NTX & Buthus mortensi & do \\
\hline Kaliotoxin & Buthus mortensi & Potent inhibitor for $\mathrm{K}^{+}$channels \\
\hline Iberitoxin & Buthus tamulus & Block squid $\mathrm{K}^{+}$Channels \\
\hline BgK & Bunodosoma granulifera & Suppresses $\mathrm{K}^{+}$current in rat dorsal ganglion \\
\hline
\end{tabular}




\section{Current Trends in Biomedical Engineering \& Biosciences}

\begin{tabular}{|c|c|c|}
\hline ShK & Stichodactyla heliantus & Blocks Kv 1.3 type $\mathrm{K}^{+}$channels in Jukrat T-lymphocytes \\
(c) Cl channel inhibitors & L.quinquestriatus. & Rat colonial epithelial cells \\
\hline Chlorotoxin (ClTx) & Crotalus scutulatus & Block chloride channels \\
\hline Chlorotoxin (ClTx) & Ampulex compressa & Blocks synaptic transmission \\
\hline Chlorotoxin (ClTx) & &
\end{tabular}

\section{Cl- Channel Blockers}

Chlorotoxin (ClTx) is a small neurotoxic peptide isolated from the venom of L.quinquestriatus. It contains 36 amino acids with eight cysteine residues [36]. It acts as a specific reversible inhibitor of chloide channels of rat colonial epithelial cells [37]. Similarly toxin isolated from Mojave rattlesnake Crotalus scutulatus inhibits calcium channels [38] while toxin from wasp Ampulex compressa venom inhibit synaptic transmission and block chloride channels in cockroach [39] (Table 2C). Besides this, hemolysins secreted by pathogenic bacteria are also seem to function like chloride channel blockers which form pores in the plasma membrane of erythrocytes and through these pores pathogens enter inside the erythrocytes and affect ionic permeability and hemoglobin concentration. Another category of extra cellular toxins is leukocidins, which interrupt the phagocytosis of bacteria by leukocytes. Other proteins are streptomycin $\mathrm{O}$ and streptomycin $\mathrm{S}$, which attack the cell membrane of many cells (Table 2).

\section{Action of Animal Toxins on Cancer Cells}

Animal venom toxins display profound anticancer effects and are potential therapeutic agents. Toxins purified from snake; bee and scorpion venoms effect cancer cell proliferation, migration, invasion, apoptotic activity and neo-vascularization. Their action mechanism on cancer cells is similar to that of chemotherapeutic agents. Lebein is a snake venom disintegrin which generates anti-angiogenic effects by inhibiting vascular endothelial growth factors (VEGF). Scorpion (Androctonus bicolor) venom exhibits cytotoxicity and induces cell cycle arrest and apoptosis in breast and colorectal cancer cell lines. BmKn-2 scorpion venom peptide demonstrates specific membrane binding, growth inhibition and apoptogenic activity against human oral cancer cells.

BmKn-2 toxin peptide isolated from scorpion species is a good candidate which has been therapeutically tested for treatment on oral cancer. It exerts selective cytotoxic effects on human oral cancer cells by inducting apoptosis via a p53-dependent intrinsic apoptotic pathway [40]. It induces potent cytotoxic effects towards both HSC4 and KB cells with the associated induction of apoptosis and showed minimal effects on healthy tissue. The venom of $A$. bicolor scorpion does selective induction of apoptosis in MDA-MB-231 and HCT-8 cells and arrest cell cycle in them. Encapsulated scorpion venoms from Androctonus bicolor (AB), Androctonus crassicauda (AC), and Leiurus quinquestriatus (LQ) [41] exhibit better anti-cancer efficacy on the colorectal cancer cell line.
Malignant gliomas are rarely curable malignant tumors arise in the central nervous system. Chlorotoxin (CTX) peptide isolated from scorpion venom, selectively target malignant gliomas. It blocks glioma $\mathrm{Cl}(-)$ channel activity and shows anti-angiogenic properties (Table 1). Similarly, an analgesic-antitumor peptide (AGAP), derived from scorpion toxin polypeptides showed antitumor activity. Polybia-MPI shows good antitumor activity [42]. Hemilipin a heterodimeric phospholipase A2 (sPLA2) from Hemiscorpius lepturus scorpion venom displays anti- angiogenesis both in vitro and in vivo [43]. This property remains intact even chemical treatment with p-bromophenacyl bromide that abolishes its enzymatic activity.

\section{Honeybee Toxins}

\section{Melittin: an Anticancer Peptide}

Bee venom is a mixture of proteins, polypeptides and low molecular weight aromatic and aliphatic constituents in variable amounts. It also contains some important enzymes i.e. phospholipase A, hyaluronidase, acid phosphatase and D-glucosidase which are highly antigenic. Honey bee wasp venom contain many toxic substances such as melittin, adiapin, apamine, bradykinin, cardiopep, mast cell degranulating peptide, mastoparan, phospholipase A2 and secapin. These toxin components have wider therapeutic applications [2]. Melittin triggers lysis of intracellular membrane found in mitochondria while PLA2 and melittin act synergistically, breaking up membranes of susceptible cells and enhancing their cytotoxic effect [44]. This cell damage, in turn, triggers the release of other harmful compounds, such as lysosomal enzymes from leukocytes, serotonin from thrombocytes, and histamine from mast cells which leads to sever pain. Mellitin also interacts with RBC membranes and induce biochemical changes/disorders in lipid protein matrix both in hydrophobic core of lipid bilayer and at polar/non-polar interface of RBC membranes. Moreover, mellitin does rigidization of lipid bilayer and alter reorganization of lipid assemblies and membrane protein rearrangements. It consequently changes the lipid protein interactions. In bees, concentration of mellitin production varies with the weather changes. Honeybee toxins cause allergy by immune-stimulation of the body [45]. These also show antimicrobial $[5,46]$, anti-cancer [47] and antitumor activity both in vitro and in vivo [48]. Animal toxins act as antibiotics against microbial infections $[49,50]$ (Table 1$)$.

Honey bee venom inhibits significantly nonenzymatic lipid peroxidation and displays a considerable hydroxyl radical 
scavenging activity [51]. Melittin causes apoptosis, necrosis and lysis of tumor cells and finally inhibits the tumor growth [48]. It also affects functions of several cell types such renal, lung, liver, prostate, and bladder, breast, and leukemia cancer cells. When melittin is treated with natural detergent it form tetramer aggregates on membranes, it leads to disorders in the structure of phospholipid bilayers. It causes changes in membrane potential, and does aggregation of membrane proteins, and does induction of hormone secretion [52]. It causes membrane disruption and interact with enzymatic systems, such as G-protein [53], protein kinase C [54], adenylate cyclase [55], and phospholipase A [56]. Melittin inhibits calmodulin, a calcium-binding protein that plays a crucial role in cell proliferation [57].

Tumoral cells contain anionic phospholipids, mainly phosphatidylserine on the external leaflet of the plasma membrane [58]. To these leaflets melittin binds preferentially as it possesses cationic charges more than normal cells. It displays anti-proliferative [59,60] and anti-angiogenic activity against cancer cells in vivo [61-63]. Conjugation of melittin to an antibody enhances its target specificity and minimizes cellular effects on normal cells. Further, for minimizing the cellular effects pro-cytolytic melittin systems are developed by associating melittin to transporting carriers. However, to enhance action of melittin on cancer cells melittin-based recombinant immunotoxins are prepared by fusion of genes that encode an antibody fragment derived from the murine monoclonal antibody K121 with an oligonucleotide encoding melittin [64]. Recombinant immunotoxins of melittin are also prepared and an anti-asialoglycoprotein receptor (ASGPR) single-chain variable fragment antibody ( $\mathrm{Ca}$ ) is attached to them. It increases target specificity and ASGPR-specific cytotoxicity to hepatocellular carcinoma cells [65]. MMP2 cleavable melittin/avidin conjugates are also (pro-cytolytic) prepared by conjugation with tumor matrix metalloproteinase 2 which usually found over-expressed on cancer cell membranes [66]. Though, when melittin coupled to avidin becomes inactive but upon release from the conjugate it induces immediate cell lysis [67]. Further, mixture of melittin with the anionic detergent sodium dodecyl sulfate formulated into poly (D), L-lactide-co-glycolide acid) (melittin-loaded nanoparticles) shows better inhibitory action against breast cancer MCF-7 cells [68] (Table 1).

Pegylated immune-liposomes are melittin carriers made by coupling to a humanized anti-hepatocarcinoma single-chain antibody variable region fragment loaded with a bee venom peptide fraction [69]. A similar immunoliposome is also prepared by using antibody trastuzumab as targeting agent and melittin as main cargo. Both components combat HER2-overexpressing human breast cancer cell lines [70]. These nanoparticles in spite of goodness are not suitable for systemic administration because melittin is released in blood vessels during transport. It is disrupted by the lytic peptide [71]. Further, ultra-small diameter melittin-nanoparticles ( $\alpha$-melittin-NP $<40 \mathrm{~nm}$ ) are also prepared which work in vivo with few side effects $[72,73]$. This nanoparticle comprises 1,2 dimyristoyl-sn-glycero-3-phosphatidylcholine
(DMPC) decorated with the hybrid peptide formed by peptide D-4F and melittin via a GSG linker. This peptide D-4F mimics highdensity lipoprotein (HDL) [74]. Serine-substituted melittin (Mel-S) showed more cytotoxic effects than asparagine-substituted melittin (Mel-N) against E. coli [75]. Interaction between melittin and the red blood cells is electrostatic that also does collapse of the membrane structure and liberation of the cell contents [76]. Though, peptide remains in a low alpha-helical conformation which forces its stabilization.

\section{Wasp Venom}

Wasp venom possesses various short peptides and enzymes which are similar to honey bee. It also contains higher percentage of mastoparan and bradykinins. Mastoparan is a membrane-active amphipathic peptide containing Ile-Asn-Leu-Lys-Ala-Leu-AlaAla-Leu-Ala-Lys-Lys-Ile-Leu-NH2 in its main amino acid chain [77]. It is rich in hydrophobic and basic residues that form its amphipathic helical structures. Mastoparan possess capacity to make pores in membranes that induces a potent mitochondrial permeability transition that affects tumor cell viability [78]. Its mode of action depends on cell type, but it also involves exocytosis. Upon interaction mastoparan induces secretion of histamine from mast cells, platelets and chromaffin cells secrete serotonin and catecholamines. Its action in the anterior pituitaryleads to prolactin release [79]. In histamine secretion, mastoparan interference with G protein activity, stimulate the GTPase activity in subunits. It also promotes dissociation of bound GDP from the protein, enhance GTP binding. Mastoparan shortens the lifespan of active G protein and induces $\mathrm{G}$ protein-mediated signaling cascade. It leads to intracellular $\mathrm{IP}_{3}$ release and maintain influx of $\mathrm{Ca}^{2+}[80]$. It inserts into the membrane bilayer causing membrane destabilization with consequent lysis [81]. It also perturbs transmembrane signaling [82-84]. Upon direct interaction it stimulates phospholipases, does mobilization of $\mathrm{Ca}^{2+}$ from mitochondria and sarcoplasmic reticulum, and causes cell death by necrosis and/or apoptosis $[85,86]$. Mastoparan induced caspase-dependent apoptosis in melanoma cells through the intrinsic mitochondrial pathway protecting the mice against tumor development [87]. Mastoparan also interacts with the phospholipids found in mitochondrial membrane. It induces permeabilization in cyclosporine A-sensitive and insensitive manners but does not interact with any specific receptors or enzymes [88]. Both PS (phosphatidylserine) and PE (phosphatidylethanolamine) lipids synergistically combine and enhance membrane poration by MP1. Presence of these lipids in the outer leaflet of cancer cells is highly significant for MP1's anticancer action [42] (Table 1).

\section{Partial Modifications}

\section{Change in Hydrophobicity}

Amino acid substitutions in hydrophobic region of toxins lead to increase in ionic interaction with membranes. Further, hydrophobic interactions also increase target specificity of toxins. Hydrophobic effect is responsible for the separation of a mixture of oil and water into its two components. It also leads to formation of protein complexes with small molecules and also assists in vesicles 
formation, protein folding, and insertion of membrane proteins into the nonpolar lipids [89-92]. In proteins hydrophobic amino acids such as alanine, valine, leucine, isolecuine, phenylalanine, tryptophan and methionine are found in cluster. Normally water soluble proteins possess a hydrophobic core in aqueous medium, and its side chains buried in water. It stabilizes and keep protein molecule in folded state. More exceptionally charged polar side chains are situated on the solvent-exposed surface where they interact with surrounding water molecules. More often, protein folding depends on minimum number of hydrophobic side chains exposed to water [93-95]. Further, substitutions of hydrophobic amino acids with non hydrophobic amino acids increase protein folding and formation of hydrogen bonds within the protein which stabilizes protein structure $[96,97]$. But L-Pro substitutions in polybia-MPI induce significant reduction of antitumor activity because of alpha-helix conformation. Amino acid substitutions in positions $2,3,5,6,8,9$, and 10 in anoplin analogs increase their surface charge/hydrophobicity that increases hemolytic activity [98].

\section{Interaction of Toxins with Protein Receptors or Protein- Protein}

For maintaining biological and pharmacological activities membrane-peptide interactions are highly important. More often, membrane potential plays a key role in ionic transport across membrane. Most cell membranes are electrically polarized; they possess inside negative charge nearly 260 millivolts (mV). Their excitability depends on ionic transport across membrane and energy conversion mainly chemical transport through impulse conduction. During membrane transport some molecules pass through cell membranes because they dissolve in the lipid bilayer. In animal cells a high concentration of $\mathrm{K}^{+}$and a low concentration of $\mathrm{Na}^{+}$relative to the external medium are found. This ionic gradient is generated by $\mathrm{Na}^{+}-\mathrm{K}^{+}$ATPase pump which operates specific transport system. Upon hydrolysis of ATP this pump provides the energy required for the active transport of $\mathrm{Na}^{+}$out of the cell and $\mathrm{K}^{+}$into the cell that also generates gradients. ATPase, requires $\mathrm{Mg}^{2+}$ for hydrolysis of ATP.

Modification of surface charges contributes to modulate biological activities of toxins. It also leads to increase the receptor interactions and formation of membrane-peptide complexes [99]. For formation of membrane-peptide complexes, mode of interaction is highly important. It assists in analyzing dynamic properties and the contact residues of the membrane-bound peptide [99]. Mastoparan is an amphiphilic tetradecapeptide extracted from social wasps Polistes flavus that is cytotoxic in nature. It interacts with the lipid bilayer using its hydrophobic side chain. This replacement of hydrophobic side chains with basic amino acids found in MP fragments enhanced the inhibitory effects on ACh-evoked catecholamine release [100]. Mastoparan activate GTP-binding regulatory proteins (G-proteins) that couple phospholipase C [79]. Mastoparan-X C-terminal 12 residues take $\alpha$-helical conformation upon binding to the phospholipid bilayer. Similar conformation-activity relationships are also observed in mastoparan analogs as activators of G-proteins [101].
Mastoparan, induces various biological functions including histamine release from rat peritoneal mast cells. In this process acidic residues play an important role in modulating the peptides' lytic and biological activities [102]. More specifically, for the activation of mast cells by mastoparan, at least two positively charged side chains are required on the hydrophilic side of the amphiphilic structure of the peptide [103]. Mastoparan enhances the GTPase activity of recombinant $\mathrm{G}(0)$ alpha 5-fold in phospholipid vesicles.

\section{Removing Toxicity of Peptides}

Animal toxins despite their toxic effects to mammalian cells they could be used as antibiotics if their toxicity is removed. They can be used template to design new potential drugs. For example inclusion of an arginine and an isoleucine residue at positions 5 and 8 reduce toxicity of mastoparan, turning it into a potential drug for infectious diseases [104]. They have been proved better candidates due to their lesser toxic effects and higher selectivity upon chemical modification and charge optimization. For lowering the toxic effect, the toxin part of the toxin molecule could be modified either into simple non toxic group, or fused to an antibody or carrier ligand. Such molecules can be used to target malignant brain tumor in patients. Contrary to this, amino acid substitution in toxin peptides increases its biological action. When melittin an insect-derived antimicrobial peptide (AMPs) isolated from Apis mellifera and Apis cerana faces substitution of serine (Ser) to asparagine (Asp). Serine-substituted melittin (Mel-S) showed more cytotoxic effect than asparagine-substituted melittin (Mel-N) against E. coli. Similarly, Mel-N and Mel-S showed different inhibitory effects on the production of IL- 6 and TNF- $\alpha$ inflammatory factor in BV-2 cells [75].

The specific biological activity of animal toxins can be practically substitution of amino acids. Though all proteins are inactivated by heat treatment but they become pharmacologically unfit. For example low toxicity of the soybean Agglutinin when given orally, as compared to its rather high toxicity when injected, is noteworthy, because the observations with other bean agglutinins are quite different. For reduction of toxic effects of animal toxins non-toxic or random peptides are obtained from SwissProt and TrEMBL and amino acid substitutions are made in natural toxins accordingly. With this minimum mutations in peptides are being made for increasing or decreasing their toxicity, and toxic regions in proteins are cleaved or change to non toxic region.

It is highly advantageous in small peptides because it enhance their specificity, high penetration, and therapeutic efficacy. Further, prediction models are prepared by using various databases and shortening of certain residues like lys, Cys, His, Asn, and Pro are abundant as well as preferred at various positions in toxic peptides. From natural toxin proteins/peptides various motifs are extracted this information is used for development of dipeptidebased model or a hybrid model that shows low toxicity in vivo experiments. ToxinPred is a unique in silico method of its kind, which will be useful in predicting toxicity of peptides/proteins. In addition, it will be useful in designing least toxic peptides and discovering toxic regions in proteins (Figure 5). 


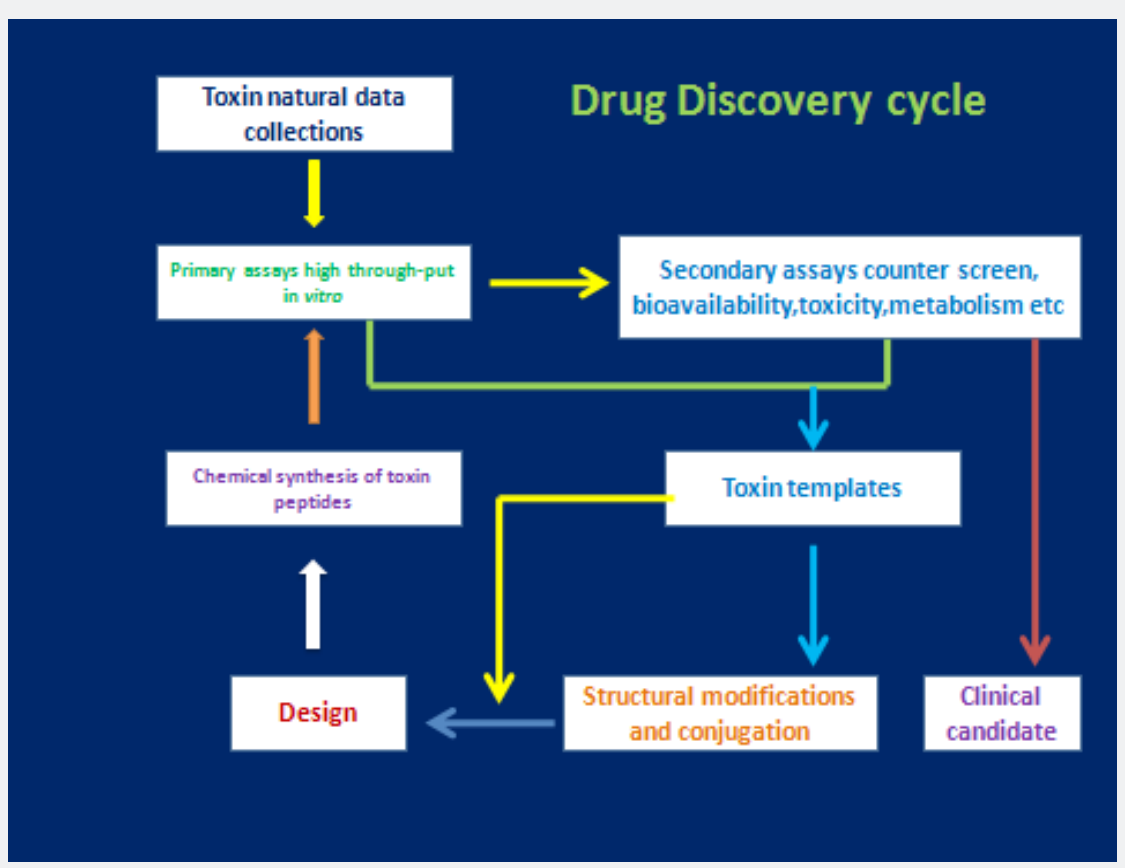

Figure 5: Use of toxin templates for discovery of anticancer drugs.

\section{Toxin and Lipid Interactions}

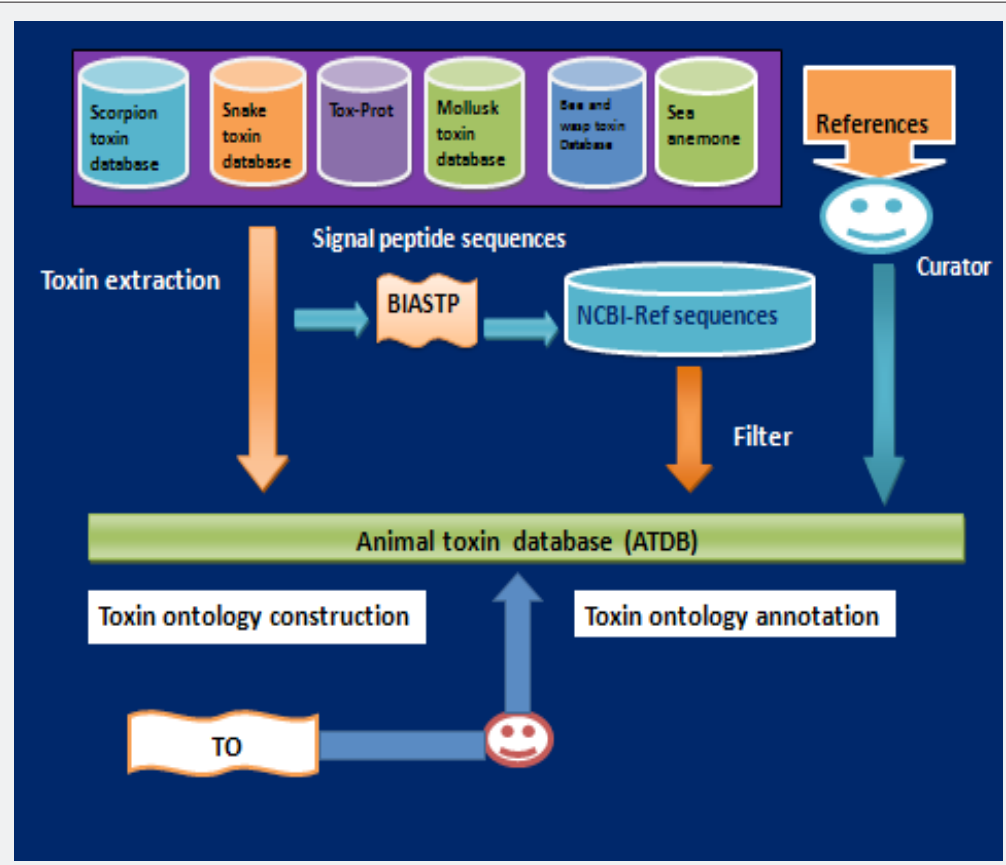

Figure 6: Showing use of structure and activity related information about toxins from animal toxin database for preparing ontology construction.

The maintenance of cell membrane integrity is a dynamic process regulated by the living cell in order to provide discrete extracellular and intracellular compartments and within the cell, separation into subcellular organelles. A major component of this integrity is the preservation of the ionic gradients which are necessary for cell function. Toxin molecule insertion into the lipid bilayer generates pores; disturb its ionic equilibrium mainly fine balance of the ion gradients across membrane. It also makes changes in the intracellular water content that results in cell death. A large number of toxin peptides interact directly with lipid components (lipid domains) of the cell membrane and form pores $[105,106]$. These pore-forming toxins are typically amphipathic polypeptides containing both hydrophilic/polar domain (s) and hydrophobic/non polar domain(s) structures. Though, these vary in size from small peptides to oligomers and up to large macromolecules. These pore forming toxins display 
increased permeabilization and do disruption of the cell plasma membrane though they show different biological origin, structure or size (Figure 6). The pore formation by toxins leads to a colloidosmotic process of the cell followed by swelling. This is a primary event in toxin-cell plasma membrane interaction, starts with pore formation. An example is pardaxin is a small pore forming peptide toxin secreted by Pardachirus marmoratus fish, which targets the plasma membrane via hydrophobic/lipophilic interactions with plasma membrane phospholipids and penetrates into the cell membrane [107]. Furthermore, pore formation triggers few secondary events such as $\mathrm{Ca}^{2+}$ overload, PLA2 activation, eicosanoid production, secretion, endonuclease activation, and cytokine release and protein phosphorylation. All these events constitute secondary cascades of toxin action which eventually lead to cell death [108].

Similarly, protonectin, a peptide isolated from the venom of the wasp Agelaia pallipes pallipes, promotes mast cell degranulation and chemotaxis in polymorphonucleated leukocytes. It possesses amphipathic features which lead to increase in its biological activity [109]. It shows preferential interaction with the micelle and presents a higher helical structure in aqueous medium. Melittin is a amphiphilic helical molecules that binds with calmodulin. Similarly, mastoporan also binds to the two $\mathrm{Ca}^{2+}$ binding proteins troponin $\mathrm{C}$ and calmodulin [110]. Enzyme phospholipase A2, specifically a soluble form (sPLA2) is secreted in venom of insects, reptiles and mammals. PLA2 belongs to family of housekeeping enzymes that specifically cleave the sn-2 fatty acid of phospholipids attached to the glycerol backbone. This enzyme causes severe damage to the lipid membrane. PLA2 operate in phospholipid cellular catabolism, and does hydrolysis of phosphatidylcholine, generate lyso-phosphatidylcholine and AA [111]. Besides this, membrane-associated iPLA2 also affect number of activities such as lipid metabolism and membrane remodeling, maintenance of mitochondrial integrity, signal transduction, cell differentiation, proliferation and viability [112]. Some of the toxic effects of PLA2 render its binding to specific receptors to which other venom components and the mammalian sPLA2 binds [113]. These sPLA2 enzymes are $\mathrm{Ca}^{2+}$-dependent and contain a His-Asp motif in the catalytic domain. Individual sPLA2 exhibit unique tissue and cellular distribution and provide precursors for pro and anti-inflammatory lipid mediator synthesis. It regulates membrane lipid composition. Snake and bee venoms contain different forms of SPLA2 toxins. One of the helices of group III sPLA2 enzymes is hydrophobic that enables its binding to the lipid bilayer membrane [114].

PLA2 found in bee venom consists of a single polypeptide chain of 130 amino acid residues folded by four disulfide bridges and a glycosyl residue at Asp-13 with a molecular weight of 15.8 $\mathrm{kDa}$. The PLA2 from bee venom causes a variety of inflammatoryassociated pathologies, including rheumatoid arthritis, septic shock, psoriasis, and asthma [115]. PLA2 stimulates PLA2R1 receptors which mediate the neurotoxic effect. A mild dose of PLA2 (6.2 mg/kg) causes edema, myonecrosis, prolonged the partial thromboplastin time and reducing the plasma fibrinogen concentration [116]. Similarly, melittin isolated from honeybee Apis mellifera is a small linear peptide composed of 26 amino acid residues. Its amino-terminal region predominantly is hydrophobic while its carboxy-terminal region is hydrophilic due to the presence of a stretch of positively charged amino acids. This amphiphilic property is responsible for its cationic surfactant properties and cytolytic activity [117]. Contrary to this, monomeric melittin does not contain sPLA2 activity by itself. Actually, it facilitates the activation of the endogenous cell housekeeping PLA2 activity of the target via rapid binding to the membrane by hydrophobic interaction with zwitterionic phospholipids. This causes disruption of the phosphate group orientation and changes in physical and steric properties of the phospholipid, which result in dislodging of membrane barrier function [117].

PLA2 forms melittin-phospholipid domains after dissolving into the hydrocarbon region of the bilayer. The highly charged $\mathrm{C}$ region and the amino phosphate dipole have a strong electrostatic interaction that results in membrane perturbation, rendering the lipid target susceptible to PLA2 cleavage [118]. It also leads to alteration of the membrane surface results in antibacterial and hemolytic activity. Melittin stimulates PLA2 in various cells and tissues, mainly human erythrocytes, anterior pituitary tissue, pancreas, rat adenohypophysis, vascular endothelial cells, human leucocytes, platelets [119] and neurons [120]. Melittin dansylated analogue (DNC-melittin) binds to natural membranes and show cytolytic activity [76]. Due to these properties melittin is used as a neurochemical tool to recognize the role of SPLA2 in modulating synaptic transmission [120]. Bee venom group III sPLA2 shows protective immune responses against a wide range of diseases including asthma, Parkinson's disease, and drug-induced organ inflammation [121]. This is widely used as a component of antivenom and for desensitization therapy against bee stings [122]. Due to membrane penetration activity and cytotoxic effects melittin is used in cancer therapy. It is used either as an active ingredient or as an absorption enhancer [123].

\section{Interaction with the Plasma Membrane}

Voltage-gated ion channels open or close depending on the setting of voltage gradient across the plasma membrane. Normally for vital functions ions are conducted through the channels down their electrochemical gradient. It depends on ion concentration and plasma membrane potential. These ion channels at large are selectively targeted by certain toxins scorpion [124] and snake venoms [125]. Voltage-Gated Potassium Ion Channels (Kv)The voltage-gated $\mathrm{K}^{+}$channels are trans-membrane channels specific for $\mathrm{K}^{+}$ions and are sensitive to voltage changes in the membrane potential [126]. These channels are known mainly for their role in repolarizing (voltage-dependent $\mathrm{Kv}$ ) the cell membrane following action potentials, which regulate cellular processes such as $\mathrm{Ca}^{2+}$ signaling, cell volume, secretion, proliferation and migration [127]. Kv channels usually have a homo-tetrameric structure. The transmembrane domain, the _-subunit, consists of six helices (S1-S6) forming two structurally and functionally different parts 
of the tetrameric channel: a potassium ion-conducting domain (pore domain), helices (S5-S6) located in the channel center and a domain sensible to changes in the membrane potential (voltagesensing domain, VSD), helices (S1-S4) located on the channel periphery. A large number of polypeptide ligands of Kv channels have been found in the venoms. Apamin and Tertiapin from bee venom target mostly KCa and Kir channels; while from scorpions Charybdotoxin and Kaliotoxin, target KCa channels.

Ion channels are important portals for a variety of toxins interacting with the plasma membrane [128]. Under normal conditions, the physiological role of these channels is to regulate with high selectivity, the transfer of cations or anions in order to maintain a resting membrane potential and to control action potentials in excitable tissues. There are many different types of ion channels, classified by their gating characteristics and by the type of ion passing through. These channels very effectively transport ions in a time frame period of milliseconds, often rising to 106 ions per second or greater. In view of the importance of ionic gradients for maintaining neuronal, cardiac, skeletal or smooth muscle tissue functions, numerous toxins, which modulate ion channel conductance and/or kinetics by serving as either channel openers or blockers with different selectivity, have been investigated. It has been well established that most $\mathrm{Na}^{+}, \mathrm{K}^{+}$, $\mathrm{Ca}^{2+}$ and some $\mathrm{Cl}$ channels, are voltage-gated [129] but others including certain $\mathrm{K}^{+}$and $\mathrm{Cl}^{-}$channels, transient receptor potential (TRP) channels, ryanodine receptors and IP3 receptors, are relatively voltage-insensitive and are gated by second messengers and other intracellular and/or extracellular mediators [130].

\section{Enhancing Cytolytic Functions}

Both ionic and peptide interactions assist in enhancement of cytotoxicity in cells. Melittin is an example that it from different conformational change in aqeous medium than mastoparan. In an aqueous solution, melittin went from a nonhelical form to an alpha helix when phosphate was added to the solution. The binding of melittin to the membrane results from electrostatic interactions, not hydrophobic interactions. Animal toxins act on several major portals consist of ion channels, pumps, transporters and ligand gated ionotropic receptors and disturbing the intracellular ion homeostasis. Scorpion toxins interact with group of portals consists of G-protein-coupled and tyrosine kinase receptors. After interaction with toxins, cell machinery alters second messengers towards pathological levels. Toxins also affect metabolic functions of subcellular organelles such as mitochondria, nucleus, protein and RNA-synthesis machineries, cytoskeletal networks and exocytic vesicles. A fundamental similarity occurs in different toxins with respect to the site of action and the secondary messengers and signaling cascades they trigger in the host; hence toxins are grouped according to their nature of action. But interaction with the initial portal is largely determined by the chemical nature of the toxin. After incorporation or import of toxin inside the cell, several ubiquitous second messengers and protein kinases/ phosphatases pathways are impaired, which also justify toxic effects? Therefore, toxins represent one of the most promising natural molecules for developing novel therapeutics that selectively target the major cellular portals involved in human physiology and diseases.

Besides, cell cytoplasm, cytoskeleton, mitochondria play a major role in regulating cell death, which occurs upon permeabilization of their membranes. Once mitochondrial membrane permeabilization (MMP) occurs, cells die either by apoptosis or necrosis. MMP is regulated by levels of calcium, and cellular redox potential mainly levels of reactive oxygen species. Besides this mobilization and targeting to mitochondria of Bcl2 family members are also important factors [131]. Melittin can induce apoptosis of human gastric cancer (GC) cells through the mitochondria pathways, and it may be a potent agent in the treatment of human GC [132]. BV treatment can be useful for protection of neurons against oxidative stress or neurotoxininduced cell death. BV treatment inhibited the activation of JNK signaling and cleaved caspase- 3 related to cell death and increased ERK phosphorylation involved in cell survival in rotenone-treated NSC34 motor neuron cells [133]. Melittin is one of the best-studied antimicrobial peptides, and many studies have focused on the membrane underlying its membrane-disruptive activity. melittin is involved in the mitochondria- and caspasedependent apoptotic pathway in C. albicans. Our findings suggest that melittin possesses a dual antimicrobial mechanism, including membrane-disruptive and apoptotic actions [134].

From wasp and honey bee venom potent cytotoxic peptides can be derived that could used after surface modification and to give them target specificity to kill tumor cells. Both mastoparan and mitoparan are cell-penetrating peptides (CPPs) have potential pharmaceutical application in delivering macromolecules into cells [135]. CCPs also affect transport of doxorubicin encapsulating Tf-liposomes across BBB [136]. Transportan and some derivatives have the capacity to carry macromolecules [137-139]. Although mastoparan showed efficient translocation, the other CPPs, namely TAT peptide and penetratin, were more efficient. On the other hand, there is a chimeric galanin-mastoparan peptide called transportan, which contains the first 13 amino acids from the highly conserved amino-terminal part of galanin and the 14 amino acids sequence of mastoparan in the carboxyl terminus $[140,137]$.

For targeting can cancer cells recombinant molecules are being made which are used as targeted toxins, also known as immunotoxins or cytotoxins. These specifically bind to cell surface receptors which are over expressed in cancer and the toxin component kills the cell. These recom binant proteins consist of a specific antibody or ligand coupled to a protein toxin. The targeted toxins bind to a surface antigen or receptor over expressed in tumors, such as the epidermal growth factor receptor or interleukin-13 receptor. For lowering the toxic effect, the toxin part of the molecule is modified from bacterial or plant toxins, fused to an antibody or carrier ligand. Such molecules can be used to target malignant brain tumor in patients. By following similar approach However, non-toxic analog of apamin are made that bears two ornithine residues instead of arginines residues (Ap00) [141]. 
Bee venom can be used by acupuncture method to carry it to relevant sites in function of a specific disease or to acupoints. Melittin tagged with an endosomolytic agent linked to siRNA delivery system effectively stop hepatitis B virus infection [142]. Another molecule mitoparan, transports this potent cytotoxic peptide to the tumor and allows its accumulation in a controlled manner [143]. Another promising and feasible idea tested in vivo to combat cancer has been presented in the form of a patent, which discloses an ultra-small lipid nanoparticle carrying melittin with potential use in clinical practice [73]. Besides cancer treatment wasp venom kinins, polyamines are used in treatment of pain, inflammatory disease, and neurodegenerative diseases such as epilepsy and aversion [86].

Anoplin shows very high cytotoxicity efficacy, arrests MEL cells (murine erythroleukemia) in the $G_{0} / G_{1}$ phase but it could not induce apoptosis in MEL cells [144]. It inhibits proliferation of MEL cells in a dose-dependent and time-dependent manner via disrupting the integrity of cell membrane. Similarly, MP-1, is short cationic $\alpha$-helical peptide isolated from the venom of the Polybia paulista wasp, is more toxic to human leukemic T-lymphocytes than to human primary lymphocytes. It shows higher content of anionic lipids increases the level of binding of the peptide to bilayers. Polybia-MPI exhibits excellent anticancer activity and remarkably suppresses the growth of sarcoma xenograft tumors [145]. Polybia- MPI /P takes a standard $\alpha$-helix conformation in the membrane which is important for its cytotoxity on tumor cells [146]. The L-Pro substitution induces a significant reduction of antitumor activity. Polybia-MPI can be used for treatment of prostate cancer and bladder cancer, because of its lower cytotoxicity to healthy body cells [147].

\section{Scorpion Venom}

The scorpion venom is a highly complex mixture of salts, nucleotides, biogenic amines, enzymes, mucoproteins, as well as peptides and proteins (e.g. neurotoxins). Scorpion venom is composed of water, salts, small molecules, biogenic amines, peptides, proteins and enzymes. It also contains variable amount of different toxins such as neurotoxins, cardiotoxins, nephrotoxins, and hemotoxins. It also contains some enzymes i.e. phosphodiesterases, phospholipases, hyaleuronidase, glucosaminoglycans some other bio-chemicals such as histamine, seratonin, and tryptophan and cytokine releasers. The main functions of the abundant polypeptide toxins present in scorpion venoms are the debilitation of arthropod prey or defense against predators. Scorpion venoms are rich source of potential novel antitumor and anti-cancer therapeutic agents [148]. Scorpion venom fractions and toxin peptides can decrease cancer growth, induce apoptosis and inhibit cancer progression and metastasis in vitro and in vivo [149]. These toxins modulate the ion channels either by blocking the pore of the channel or by altering the voltage gating. Molecules which block the pores have been useful in deciphering the structure of the ion channels. Many scorpion toxins have already been used for probing the voltage gated sodium channels [148].
Based on their molecular size and pharmacological activity, toxin peptides are classified in to two main groups. The first group contains short toxins consisting of 30-40 amino acid residues with 3-4 disulfide bridges, which mainly affect the voltage dependent $\mathrm{K}^{+}$channels, and the large conductance calcium activated $\mathrm{K}^{+}$ channels [150]. The second group includes long chain toxin peptides of 60-70 amino acids cross linked by 4 disulfide bridges, which mainly have an effect on voltage dependent $\mathrm{Na}^{+}$channels of excitable cells [151,152]. Insect toxins are $\alpha$ insect toxins which are excitatory in nature and show depressant activity [153]. Several toxins, which specifically affect $\mathrm{Na}^{+}$and $\mathrm{K}^{+}$channels, have been exclusively studied with respect to their structure, mode of action and pharmacological properties [154,155]. In addition to it some toxins that specifically target $\mathrm{Ca}^{++}, \mathrm{K}^{+}$and $\mathrm{Cl}^{-}$channels have also been isolated [150,156] (Table 2). A $4.5 \mathrm{kD}$ peptide toxin was isolated from the venom of Palamneus gravimanus, the Indian black scorpion, to block human Kv1.1 channels expressed in Xenopus laevis oocytes. This toxin peptide selectively blocks the human cloned voltage gated potassium channel at a very low concentration (10 nM). This blockage was found to be voltage dependent. Same peptide has shown typical hypertensive symptoms and showe a $\mathrm{LD}_{50}$ value of $2-\mathrm{mg} / \mathrm{kg}$ mice (Table 1 ).

Venom peptides isolated from several scorpion species showed multiple biological activities such as cytotoxic, antiproliferative and apoptogenic effects on cancer cells [157]. Scorpion venom from Androctonus australis hector (Aah) and its toxic fractions (FtoxG-50 and F3) shows strong effect onon NCI-H358 human lung cancer cells [158]. BmKn-2 exerts selective cytotoxic effects on human oral cancer cells by inducting apoptosis via a p53dependent intrinsic apoptotic pathway [40]. Similarly, A. bicolor venom exert cytotoxic effects on MDA-MB-231 and HCT-8 cells in a dose- and duration-dependent manner and induced apoptotic cell death. A. bicolor venom arrests the cancer cells in G0/G1 phase of cell cycle and induces apoptosis in breast and colorectal cancer cell lines [159] (Table 1).

These venom peptides are highly active and specifically target all major ion channels such as $\mathrm{Na}^{+}, \mathrm{K}^{+}, \mathrm{Cl}^{+}, \mathrm{Ca}^{++}$and rynodine sensitive $\mathrm{Ca}^{++}$channels [160] and their subtypes both in vertebrates and invertebrates [161] (Table 2). The devastating potency of these toxins causes massive and recurring depolarization of nerve and muscle cells simultaneously makes prey disables or kills it. The most potent animal toxin is the neurotoxin, which occurs in form of both short and long chain low molecular weight peptides. Both are heat stable and cause cell impairment in nerves, muscles and alter ion channel permeability. The long chain polypeptides of neurotoxins cause stabilization of voltage dependent sodium channel and induce repetitive firing of the somatic, sympathetic and parasympathetic neurons. This repetitive firing results in autonomic neuromuscular excitation and prevents normal nerve impulse transmission. Further, it results in the release of excessive neurotransmitters such as acetylcholine, glutamate, aspartate, epinephrine and norepinephrine. The binding of neurotoxins to the host is reversible, but different neurotoxins have different affinities. The stability of these neurotoxins is due to presence of 
four-disulfide bridges and compact three-dimensional structure. There are some chemicals, which can break the disulfide bridges and inactivate the toxin by causing it to unfold. However, the antigenicity of these toxins depends on the length and number of exposed regions that are striking out of the three-dimensional structure. Being heterogeneous mixture, scorpion venom accounts for the variable reactions in envenomated patients. Further, various constituents of the venom may act directly or indirectly and individually or synergistically to exert pharmacological effects. Though scorpion species show differences in amino acid sequences but have more similar immunological properties. Thus any modification in the amino acid sequence may result in the modification of structure, which ultimately alters immune function of the toxin.

After scorpion envenomation there occurs a heavy decrease in glycogen content of liver and cardiac and skeletal muscles in rabbits. Scorpion venom also induces diabetes destroying the islets of Langerhans or beta cells and increase triglyceride level in rabbits. It also causes hyperglycemia, hypercholestemia and increases the level of free fatty acids. Therefore, increased utilization of circulating FFA also enhances oxygen consumption. It also leads to aggravate the ischemic injury to myocardium, predisposing to arthymias and heart failure. Scorpion envenomation also alters insulin secretion and disturbs the insulin/glycogen ratio, which generates an anabolic state with more nutrient incorporation in peripheral tissues. Severe scorpion envenomation causes an autonomic storm

\section{Development of Toxin Based Therapeutic Drug Delivery System}

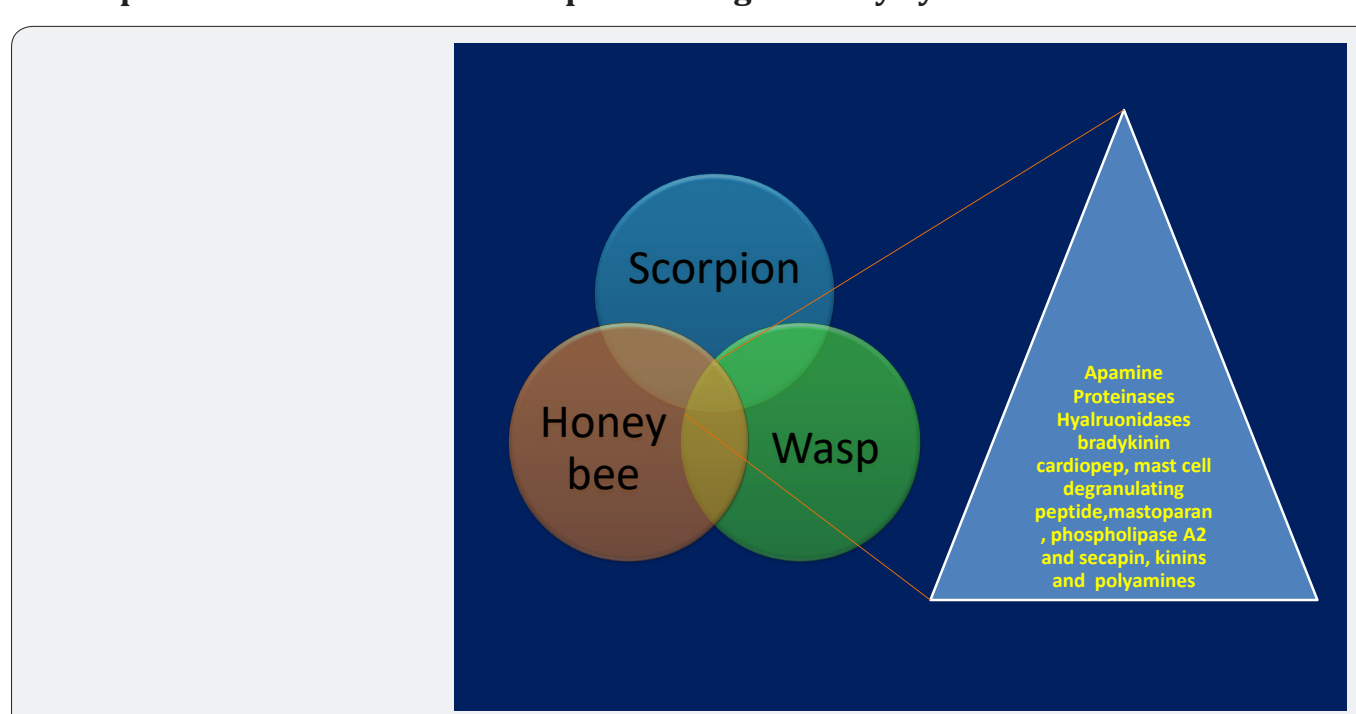

Figure 7: Showing biological composition of wasp, honey bee and scorpion peptides.

Animal toxins are natural weapons which display nonspecific cytolytic activity, rapid degradation and excretion when injected in blood. Venom peptides present in wasp and honey bee showed immense cytolytic against cancer cells when conjugated as carrier. A pro-cytotoxic systems was made by using bee venom cytotoxic peptides and its conjugation with poly (l-glutamic acid) PGA polymer through specific cleavage sequences. These were found quite sensitive to over-expressed tumor proteases, such as the metalloproteinase-2 (MMP-2) or cathepsin B. After and induces release of catecholamines. Important symptoms and signs of scorpion envenomation are vomiting, profuse sweating, absence of pain to severe excruciating pain at the site of the sting, increased salivation, generalizing tingling and numbness, priapism, tachycardia, trachypnoea, transient hypertension followed by hypotension and pulmonary edema. Besides this, scorpion envenomation by Mesobuthus tamulus concanesis Pocock) envenomation causes cardiac sarcolemmal defects displayed by alterations in $\mathrm{Na}^{+} \mathrm{K}^{+}$ATPase and $\mathrm{Ca}+$ ATPase activities, initial hypertension followed by hypotension and shock, glycogenolysis in atria, ventricle, liver, skeletal muscle, hyperglycemia, increase free fatty acid levels and reduction in triacylglyceride levels. An altered erythrocyte $\mathrm{Na}^{+} \mathrm{K}^{+}$ATPase activity is also observed in scorpion-stung patients, which result in osmotic fragility of red blood cells, insulinemia and pancreatitis. It also enhances thyroid hormones, cortisol, and angiotensin II levels and also increases the clotting time. It also causes acute reduction in platelet counts and increased lactic acid and ketoacid levels. All above changes cause multiple organ system failures along with cardiogenic pulmonary edema and Adult Respiratory distress syndrome in patients. After administration of anti-venom all such changes could make reversal. Anti-venom resulted in reversal of ECG, reduction in LDH, SGOT, SGPT, CK MB and alpha HDBI enzyme levels. It also revert the blood pressure to normal and stop the hypotension. It also cause normal glucose level and do lipogenesis following anti-venom therapy. Anti-venom successfully neutralizes the venom in circulation and other body compartments. 
PTX-CTX-FL displayed great potential for brain cancer therapy $[162,163]$ (Table 3). Besides natural toxin peptides synthetic analogues of each peptide, were engineered which also showed enhanced cationicity and amphipathicity. These also showed potent anti-proliferative activity against a range of human cancer cell lines [164]. Scorpion venom components are also used to make scaffolds for the development of drugs [165] (Figure 5). From available database on natural toxins new therapeutic molecules can be designed by using structure and activity related information (Figure 6). Further, their target specificity can be improved by finding anticancer peptides by slight modifications in amino acids, lipid-protein and toxin receptor interactions and a common peptide could possible scorpion, honey bee, and wasp and spider bites due to their long evolutionary relationship and ontology (Figure 7). Thus new putative toxin structures can be developed from naturally secreted toxins by using bio-informatics tools and methods mainly proteomic and transcriptomic library (Figure 8).

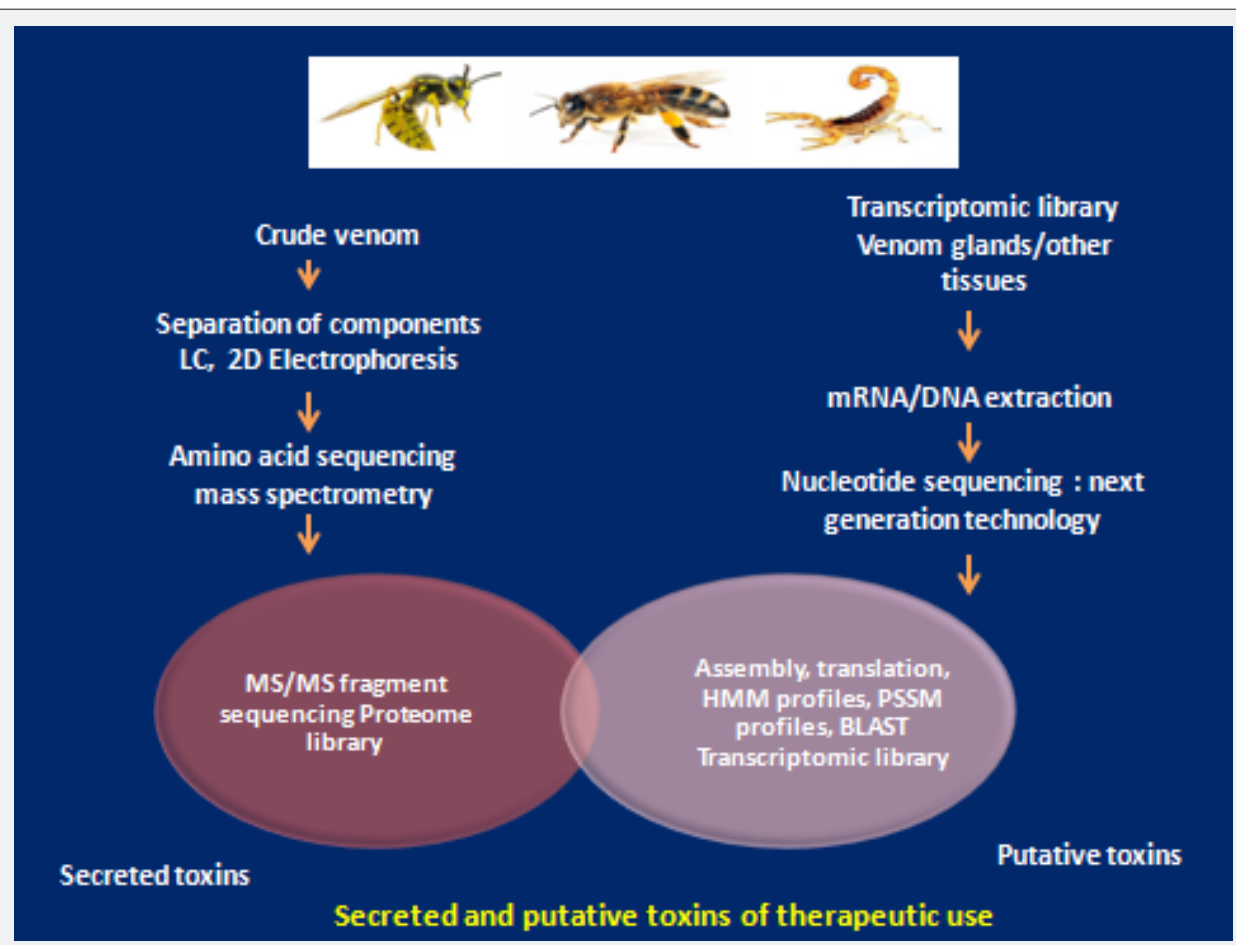

Figure 8: Showing naturally secreted toxins and methods to generate putative toxin structures by using biological tools and transcriptomic library.

Glioblastoma multiforme (GBM) is a most common malignant central nervous system tumor. This is highly malignant and aggressive and most lethal human cancers which show very high invasive capacity and lesser therapeutic options [166]. It is fast proliferating and destructive tumor has very low mean survival time $(<24$ months) and develops very silently within the brain microenvironment. These malignant primary brain neoplasm showed mean survival of < 24 months. Drug chemotherapy of GBM shows low therapeutic efficiency and systemic side effects [167]. Only glioma-specific chloride ion channel represents a specific target for therapy. These effects are achieved mainly through the blocking of an array of ion channel types within the membranes of excitable cells. These ion channel-blocking toxins are tightlyfolded by multiple disulphide bridges between cysteine residues [164]. Two nonadecapeptide FLFSLIPSVIAGLVSAIRN and FLFSLIPSAIAGLVSAIRN have shown very strong anti-tumor potential against GBM [167].

\section{Cisplatin-Based Therapy}

Cisplatin-based therapy is one of the most important chemotherapy treatments for GBM, although its efficacy is limited due to drug resistance and undesirable side effects. DMCa is a good candidate for clinical platinum-based therapy in GBM treatments and other cancer types [168]. DMCa exhibit strong anti-cancer efficacy compared to cisplatin, especially at low doses. By inducing intracellular oxidative stress, Pt-1-DMCa potentiated platinuminduced DNA damage and led to enhanced p53 phosphorylation, followed by increased activation of both mitochondrial and death receptor pathways. Decreased phosphorylated AKT and ERK levels were associated with the apoptosis induced by the novel synthesized cisplatin analogue. Thus, a chimera between platinum and a maurocalcine-derived CPP was found a highly successful anti-cancer compound that works by targeting the intracellular redox system [169] (Table 3).

\section{Chlorotoxin (CTX)-Targeted Nanoparticles Therapy}

Chlorotoxin is a disulfide-rich stable peptide derived from Israeli scorpion Leiurus quinquestriatus venom. It shows wider therapeutic potential in treatment of cancer. It possesses compact shape and is convenient for intracranial delivery. It is specific and efficacious in blocking glioma $\mathrm{Cl}(-)$ channel activity [170]. CTXconjugated NPs are preferentially bind to tumor cells and used 
as a vehicle to deliver anti-cancer drugs specifically to cancer cells [171]. Chlorotoxin (CTX)-targeted nanoparticles (NPs) work as a targeting ligand that specifically binds to glioma. CTX was conjugated onto iron oxide NPs, quantum dots, and rare-earth upconversion NPsare used in magnetic resonance and fluorescence imaging of glioma (Table 3). CTX-conjugated NPs are also used as carrier system to load anticancer drugs or therapeutic genes for targeted chemotherapy or gene therapy of glioma, respectively [172]. It targets various gated channels i.e. voltage gated chloride channels (GCC), calcium-dependent phospholipid-binding protein Annexin-2, and an inducible extracellular enzyme matrix Metalloproteinase-2 (MMP-2). MMP-2 shows anti-neoplastic potential. Chlorotoxin possess tumor cell targeting domain and shows different effector functions [173]. Further, for enhancing its action on cancer cells its physical mixture (CTX + Onc) was prepared by conjugating it to a onconase. At high dose this CTX-Onc showed better anti-tumor effect than simple toxin [174]. Similar cytotoxic potential is also reported in Centruroides tecomanus chlorotoxin [175]. In addition, multifunctional nanocomposites are made by using polymeric nanoparticles (PNPs) containing two cytotoxic agents - the drug alisertib and silver nanoparticles. These PNPs have been conjugated with a chlorotoxin, an active targeting 36-amino acid-long peptide that specifically binds to MMP-2, a receptor over-expressed by brain cancer cells [176]. This silver/alisertib@PNPs-chlorotoxin combination does tumor reduction in vivo. Similar activity is also reported in peptides CA4 and CTX-23 which effectively reduce glioma cell proliferation. In addition, CTX, CA4 and CTX-23 impact on cell migration and spheroid migration. CA4 and CTX-23 are selective and show low toxicity against primary neurons and astrocytes. These also shorten cell extensions, increased nuclear sizes and reduce tumor volume. CTX and CA4 show anti-angiogenic properties with endothelial and angiogenic hotspots disrupting activities [167]. Recombinant AGAP (rAGAP) (Analgesic-antitumor peptide) also affect the migration and invasion of HepG2 cells via a voltagegated sodium channel (VGSC) $\beta 1$ subunit and shows strong antitumor activity [177] (Table 3).

\section{Self-assembled Toxin based Polymeric Nano-Structures}

Efforts have been made to self-assemble scorpion venom in polymeric nano-structures for controlled delivery of toxins towards tumorous sites [178]. For this purpose, polypeptide extract from scorpion venom (PESV) was combined to Rapamycin. It is taken up by H22 hepatoma cells in mice during autophagy [179]. This PESV combined Rapamycin inhibit the development of H22 hepatoma transplantation tumor in mice. It could be possible by inhibiting the activity of mTOR, enhancing expressions of ULK1, MAP1LC3A, and Beclin1 [179]. PESV also inhibit the angiogenesis of H22 hepatoma. The mechanisms might be associated with suppressing the expression of PI3K, P-Akt, HIF-1 alpha, and VEGF-A [180]. PESV (polypeptide extract from scorpion venom) successfully block cell cycle and inhibit angiogenesis directly to inhibit cell proliferation of non-small cell lung cancer cell line A549 mainly through reducing the expression of HIF-1alpha, VEGF and increasing the expression of PTEN [181]. Mechanism of polypeptide extract from scorpion venom (PESV) on promoting anti-tumor effects of cyclophosphamide (CTX). In addition, polypeptide extracts from scorpion venom (PESV) combined to 5-fluorouracil (5-Fu) shows inhibition effects on vasculogenic mimicry (VM) of $\mathrm{H} 2$ hepatoma carcinoma cells in mice [182]. Similarly, TsAP-1 and TsAP-2 isolated from Tityus serrulatus showed broad spectrum anticancer potencies which can be significantly enhanced by increasing their cationicity [183]. PESV inhibit the expressions of VEGF and TGF-beta1, promote the maturation of DCs, recover its antigen uptake presentation function, and reverse the immune injury to the body by CTX. It also plays important role in inducing the tumor cell apoptosis [184]. Selectively targeting cancer tissue is one promising strategy. Similarly conjugation of toxins to platinum (IV) derivatives (Cisplatin), increase the cytotoxicity in cancer cells [185] (Table 3).

Similarly, The BmKn-2 peptide kills HSC-4 cells through induction of apoptosis [186]. This peptide displays specific membrane binding, growth inhibition and apoptogenic activity against human oral cancer cells [186]. Buthus matensii Karsch $(\mathrm{BmK})$ scorpion venom extracts inhibit growth of human breast cancer MCF-7 cells by inducing apoptosis and blocking cell cycle in G0/G1 phase [187]. miRNA-based therapeutics is followed for specific killing of tumor and cancer cells in GBM. In this therapeutic approach intravenously-administered chlorotoxin (CTX) is coupled (targeted) with stable nucleic acid lipid particle (SNALP) to formulate anti-miR-21 oligonucleotides. These particles are send to approach towards tumor cells. These particles accumulate preferentially within brain tumors and promote efficient miR-21 silencing. It results in increased mRNA and protein levels of its target RhoB and showing no signs of systemic immunogenicity. This miRNA modulation by the targeted nanoparticles combined with anti-angiogenic chemotherapy shows high success rate in GBM treatment [166]. However, for modulation of tumor response to chemotherapy, a combination of treatment with small interference RNA (siRNA), chlorotoxin and conventional (temozolomide, TMZ) drugs is used. siRNA delivery by targeted nanoparticles resulted in modulating tumor response to chemotherapy in GBM. siRNA interrupt cell signaling, drug act as toxic agent, and CTX contributes apoptotic tumor cell death [188]. Similarly a chlorotoxin-conjugated graphene oxide (CTX-GO) drug delivery system shows better efficacy in glioma treatment. The method is developed by using graphene oxide and loading doxorubicin CTX-GO (CTX-GO/DOX) via noncovalent interactions [167]. The protein chlorotoxin (CTX) has been shown to preferentially target glioma cells. The combination of CTX-NO and chemotherapeutics also led to decreased cell invasion (Table 3). A new method MiRNA-21 silencing mediated by tumor-targeted nanoparticles combined with sunitinib: is developed for gene therapy of glioblastoma [167]. Further, immunotoxin molecules conjugated to some anticancer drug are to be prepared. For targeting can cancer cells recombinant molecules are being made which are used as targeted toxins, also known as immunotoxins or cytotoxins (Figure 9). 


\section{Current Trends in Biomedical Engineering \& Biosciences}

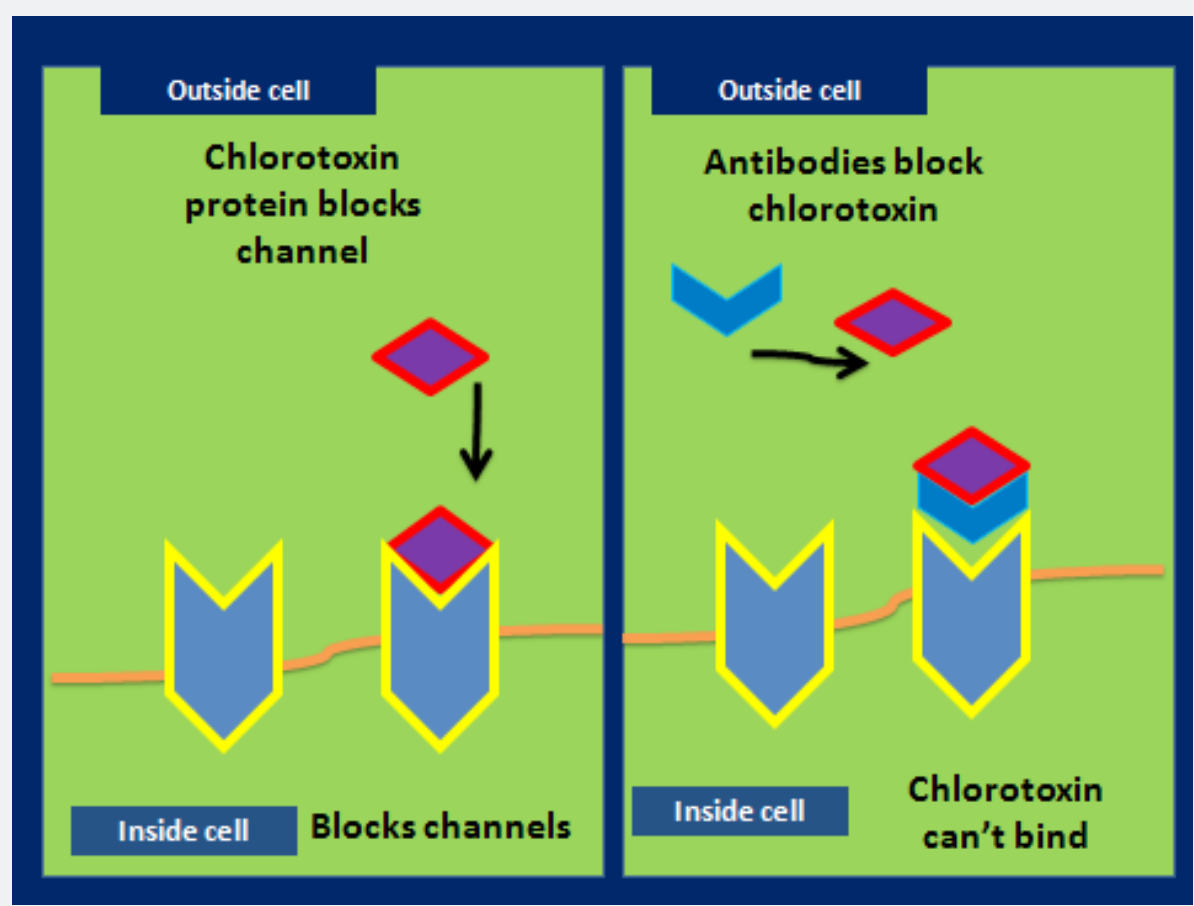

Figure 9: Showing chlorotoxin channel binding to receptors and its blockage by using antibodies.

Table 3: Animal Toxins and Nano-drug Delivery Systems Prepared for Cancer Therapeutics.

\begin{tabular}{|c|c|c|}
\hline Drug Delivery System & Therapeutic Effect & Reference \\
\hline Mastoparan and mitoparan & cell-penetrating peptides (CPPs) & [167] \\
\hline Poly (l-glutamic acid) PGA polymer & NP formulation are used to target glioblastoma multiform (GBM). & [162] \\
\hline CTX loaded on NPs & Enhance the uptake of the NPs & [162] \\
\hline Cisplatin-based therapy & clinical platinum-based therapy GBM treatments & [168] \\
\hline Maurocalcine-derived CPP & Anti-cancer therapy & [168] \\
\hline $\begin{array}{l}\text { Calcium-dependent phospholipid-binding protein Annexin-2, } \\
\text { and an inducible extracellular enzyme matrix Metalloprotein- } \\
\text { ase-2 }\end{array}$ & Anti-neoplastic therapy & [172] \\
\hline Conjugation of CTX + Onc. & CTX-Onc showed better anti-tumor effect than simple toxin & [173] \\
\hline Nanocomposites (PNPs) & $\begin{array}{l}\text { Contains two cytotoxic agents - the drug alisertib and silver nanopar- } \\
\text { ticles }\end{array}$ & [174] \\
\hline $\begin{array}{l}\text { Polypeptide extract from scorpion venom (PESV) combined to } \\
\text { Rapamycin. }\end{array}$ & Anti- angiogenesis therapy & [178] \\
\hline Conjugation of toxins to platinum (IV) derivatives (Cisplatin),). & increase the cytotoxicity in cancer cells & [184] \\
\hline siRNA delivery by targeted nanoparticles & $\begin{array}{l}\text { siRNA interrupt cell signaling, drug act as toxic agent, and CTX con- } \\
\text { tributes apoptotic tumor cell death }\end{array}$ & [187] \\
\hline
\end{tabular}

\section{Future Directions}

So far researches have been done venom from several species of wasp, homey bee and scorpion have been isolated and characterized for their multiple biological activities. Being heterogeneous mixture, animal venom accounts for the variable biological activities. These show differences in amino acid sequences but have more similar immunological properties. Thus any modification in the amino acid sequence may result in the modification of structure, which ultimately alters immune function of the toxin. Efforts should be made to remove toxicity of venom peptides and targeted drug should conjugate with toxin.
Further, anticancer property of venom peptides can be enhanced by improving its cytolytic action on cancer cells. It could further be achieved by doing encapsulation of venom toxin peptides in ultra-small lipid nanoparticle. Development of strategies for effective delivery of venom peptide could speed up anticancer therapeutics. New additions of anti-angiogenic properties could possible in many more dansylated analogue which bind to natural membranes and show cytolytic activity can be designed. Melittin produced a different conformational change than mastoparan. In an aqueous solution, melittin went from a nonhelical form to an alpha helix when phosphate was added to the solution. Further, 
binding of toxins (melittin) to the membrane can be increased by improving electrostatic interactions or molecular surface charges. Besides hydrophobic interactions several other favorable electrostatic interactions are responsible for molecular modeling. By doing this toxins can bind to cell surface receptors mainly those which over-express in cancer and delivered toxin component may kill the cancerous cell.

To fulfill the therapeutic demand of novel drugs chemical and recombinantsynthesis can be donefor obtaining promising peptide toxins. Their target specificity can be decided after structural characterization through experimental and computational methods. Further bioactivity and molecular function can be extended through biological assays and computational modeling. By performing transcriptomic and genomic analysis try to identify genes expressed in venom glands, these could assist in production of nano-venins and nano-drug carriers for treatment of glioma, pancreatic, thymus, prostate, and liver cancers. There are many more avenues which can be investigated to explore new therapeutic uses of venom components. Development of pro-cytotoxic system based on mitoparan, which transports this potent cytotoxic peptide to the tumor and allows its accumulation in a controlled manner, emerges as a plausible approach to overcome off-target side effects of current cancer treatment. Therefore, after understanding of the molecular mechanisms and target specificity of animal-secreted toxins new drug molecules could be designed. Certainly these will reduce human health risks and opens new insights into therapies against bites, and pathologies ranging from neurological disorders to cancer, using toxinomimetic agents. Recently, molecular and cellular biology dissecting tools have provided a wealth of information on the action of these diverse toxins, yet, an integrated framework to explain their selective toxicity. Though there are several toxin molecules but different toxins showed fundamental mechanisms of toxicity at different biochemical, molecular and cellular- levels with particular consideration for the nervous system

\section{Conclusion}

From researches it has been cleared that animal toxins from wasp, honey bee and scorpion possess several active molecules with anticancer activities, ranging from inhibition of proliferation and cell cycle arrest to induction of apoptosis and decreasing cell migration and invasion. These specially show cytotoxic effects in tumor and cancer cells and degrade/destroy. Scorpion venoms and toxins can decrease cancer growth, induce apoptosis and inhibit cancer progression and metastasis in vitro and in vivo. This activity depends on specific structure of peptides with biophysical properties (hydrophobicity, hydrogen bond donor and steric), to penetrate through membrane and block ion channels successfully and effect membrane environment due permeability alteration (sodium, potassium, chloride). These toxins showed heterogeneous distribution and interact with the lipid bilayer by using its hydrophobic side; and shift molecules within the lipid bilayer rather than on the surface. Upon conjugation with certain polymers and drugs these work as novel drug carriers and carry it to the targeted site. Venom peptides have potential application as an alternative or complementary medicine for the treatment of human cancers. These toxin polypeptides not only work against cancer cells but also show good antimicrobial activity and can be used to treat autoimmune diseases and cardiovascular effects. By making few chemical modifications hydrophobic properties of toxins could be changed. Further, lower down of toxicity is also possible by making amino acid substitutions, and its expression in animal model systems and cell lines can assist in improvement of the maximum tolerated dose and the pharmacokinetic parameters of cytotoxic peptides in vivo.

For finding more appropriate drugs molecular modeling played important role in increasing molecular-level understanding of the activity and specificity of animal toxins. Further, partial modifications did in peptides after amino acid shifting, and replacement engineering made them more suitable for biotechnological and pharmaceutical applications. This review focuses on the biological effects of animal venom toxins on cancer cells mainly its interaction with membranes and ion channels. However, by exploration, characterization, and optimization of toxin peptides new integrative chemotherapeutic methods can be established. Further, taxonomic and phylogenetic analyses can assist in deciphering the molecular and ionic interactions of venom peptides from various animal groups that will alternatively help in unique modeling of peptides, its linkage for target specific drug delivery. New combination can be made by using radiation therapy and toxin therapy combinations for fast recovery of tumor patients. Clinical applications in GBM therapy, intraoperative imaging, nano-probes and nano-vectors based technology; targeted chemotherapy and immunotherapy are discussed as well. Chlorotoxin is likely to play a significant role in effective GBM immunotherapy in the future.

\section{Conflict of Interest}

The author declares no conflict of interest, financial or otherwise.

\section{Acknowledgement}

Author extends his thanks to Prof R.N.K Bamezai, Former Dean, JNU New Delhi, for valuable suggestions during manuscript writing.

\section{References}

1. Chaisakul J, Hodgson WC, Kuruppu S, Prasongsook N (2016) Effects of Animal Venoms and Toxins on Hallmarks of Cancer. J Cancer 7(11): 1571-1578.

2. Ye X, Guan S, Liu J, Ng CC, Chan GH, et al. (2016) Activities of Venom Proteins and Peptides with Possible Therapeutic Applications from Bees and WASPS. Protein Pept Lett 23(8): 748-755.

3. Fenton AW, West PR, Odell GV, Hudiburg SM, Ownby CL, et al. (1995) Arthropod venom citrate inhibits phaspholipase A2. Toxicon 33(6): 763-770.

4. Massesini AR, Romano-Silva MA, Gomez MV (2003) Sodium channel toxins neurotransmitters release. Neurochem Res 28(10): 1607-1611.

5. Cestele S, Caterall WA (2000) Molecular mechanism of neurotoxin action on voltage-gated sodium channels. Biochimie 82(9-10): 883892. 
6. Zhu S, Bosmans F, Tytgat J (2004) Adaptive evolution of scorpion sodium channel toxins. J Mol Evol 58(2): 145-153.

7. Zilberberg N, Froy O, Loret E, Cestle S, Arad D, et al. (1997) Identification of structural elements of a scorpion alpha-neurotoxin i9mportant for recepter site ecognition. J Biol Chem 272(23): 14810-14816.

8. Eitan M, Fouler E, Herroann R, Duval A, Pelhate M, et al. (1990) A Scorpion venom neruotoxin to insect that affects sodium current inactivation: Purification, Primary strucuture and mode of action. Biochemistry 29(25): 5941-5947.

9. Lewis RJ, Schroeder CI, Ekberg J, Nielsen KJ, Loughnan M, et al. (2007) Isolation and structure activity of mu -conotoxins TIIIA, a potent inhibitor of tetrodotoxin sensitive voltage gated sodium channel. Mol Pharmacol 71(3): 676-685.

10. Volpon L, Lamthanh H, Barbier J, Gilles N, Molgo J, et al. (2004) NMR solution structures of delta conotoxin EVIA from Conus erminus that selectively acts on vertebrate neuronal $\mathrm{Na}^{+}$channels. J Biol Chem 279(20): 21356-21366.

11. Li RA, Ennis IL, Velez P, Tomaselli GF, Marban E (2003) Molecular basis of isoform-spesific \{micro\} conotoxin block of cardiac, skeletal muscle and brain Na+ channels. J Biol Chem 278(10): 8717-8724.

12. Moczydlowski E, Uehara A, Guo X, Heiny J (1986) Isochannels and blocking models of voltege-dependent sodium channels. Ann NY Acad Sci 479(1): 269-292.

13. Hayase F, Matsmura H, Sanada M, Kitada-Hamada K, Momatsu-Kanbe $\mathrm{M}$, et al. (2007) Inhibitory action of protein kinase Cbeta inhibitor on tetrodotoxin resistant $\mathrm{Na}+$ current in small dorsal root ganglion neurons in diabetic rats. Neurosci Lett 417: 90-94.

14. Frank Bosmans, Abel Aneiros, Jan Tytgat (2002) The sea anemone Bunodosoma granulifera contains surprisingly efficacious and potent insect - selective toxins. FEBS letters 532(1-2): 131-134.

15. Xiao Y, Tang J, Hu W, Xie J, Maertens C, et al. (2005) Jinghhaotoxin I a novel spider neurotoxin preferentially inhibiting cardiac sodium channel inactivation. J Biol Chem 280(13): 12069-12076.

16. Corzo G, Sabo JK, Bosmans F, Billen B, Villegas E, et al. Solution structure and alanine scan of a spider toxin that affects the activation of mammalian voltage -gated sodium channels. J Biol Chem 282(7) 4643-4652.

17. Oliveira JS, Zaharenko AJ, Ferreira WA, Konnno K, Shida CS, et al. (2006) BC IV a new paralyzing peptide obtained from the venom sea anemone Bunodosoma caissarum. A comparison with the sodium ion channel toxin BcII. Biochem Biophys Acta 1764(10): 1592-1600.

18. Martin- Moutot N, Mansuelle P, Alcaraz G, Dos Santos RG, Cordeiro MN, et al. (2006) Phoneutria nigriventer toxin 1: a novel, state dependent inhibitor of neuronal sodium channels that interacts with micro conotoxin binding sites. Mol Pharmacol 69(6): 1931-1937.

19. LePage KT, Goeger D, Yokokawa F, Asanom T, Shioiri T, et al. (2005) The neurotoxic lipopeptide Kalkitoxin interects with voltage sensitive sodium channels in cerebellar neurons. Toxicol Lett 58(2): 133-139.

20. Sun HY, Zhou ZN, Ji YH (2005) The role of voltage-gated Na+ channels in excitation-contaction coupling of rat heart determined by BMK I. an alpha- like Scorpion neurotoxin. Toxicol In vitro 19(2): 183-190.

21. Li D, Xiao Y, Xu X, Xiong X, Lu S, et al. (2004) Structure activity relationship of hainantoxin-IV and structure determination of active and inactive sodium channel blockers. J Biol Chem 279(36): 3773437740 .

22. Nicholson GM, Little MJ, Birinyi-Strachan LC (2004) Structure and function of delta attarcotoxins: lethal neurotoxin targeting the voltage gated sodium channel. Toxicon 43(5): 587-599.

23. Zlotkin E, Rochat F, Rochat H, Miranda F, Lisszky S (1971) Purification and properties of the insect toxin from the venom of the scorpion Androctonus australis Hecter. Biochemie 53(10): 1073-1078.
24. Catterall WA (1980) Neurotoxin that acts on voltage sensitive sodium channels in exutoble membranes. Annu Rev Pharmacol Toxicol 20: 15-43.

25. Fozard JR, Pfannkuch HJ, Schuurman HJ (1997) Mast cell degranulation following adenosine A3 recepter activation in rats. Eur J Pharmacol 298(3): 293-297

26. Littleton JT, Ganetzky B (2000) Ion channels and synaptic organization: analysis of the Drosophila genome. Neuron 26(1): 35-43.

27. Harvey AL, Vatanpour H, Rowan EG, Pinkasfeld S, Vita C, et al. (1995) Structure-activity studies on scorpion toxins that block potassium channels. Toxicon 33(4): 425-436.

28. Candia S, Garcia ML, Latorre R (1992) Mode of action of iberiotoxin, a potent blocker of the large conductance $\mathrm{Ca}(2+)$-activated $\mathrm{K}+$ channel. Biophys J 63(2): 583-590.

29. Novello JC, Arantes EC, Varanda WA, Oliveira B, Giglio JR, et al. (1999) TsTX-IV, a short chain four-disulfide-bridged neurotoxin from Tityus serrulatus venom which acts on $\mathrm{Ca}^{2+}$-activated $\mathrm{K}^{+}$channels. Toxicon 37(4): 651-660.

30. Xu Y, Wu J, Pei J, Shi Y, Ji Y, et al. (2000) Solution structure of BmP02, a new potassium channel blocker from the venom of the Chinese scorpion Buthus martensi Karsch. Biochemistry 39(45): 13669-13675.

31. Castañeda O, Sotolongo V, Amor AM, Stöcklin R, Anderson AJ, et al. (1995) Characterization of a potassium channel toxin from the Caribbean Sea anemone Stichodactyla helianthus. Toxicon 33(5): 603613.

32. Cotton J, Crest M, Bouet F, Alessandri N, Gola M, et al. (1997) A potassium-channel toxin from the sea anemone Bunodosoma granulifera, an inhibitor for Kv1 channels. Revision of the amino acid sequence, disulfide-bridge assignment, chemical synthesis, and biological activity. Eur J Biochem 244(1): 192-202.

33. Cai Z, Xu C, Xu Y, Lu W, Chi CW, et al. (2004) Solution structure of BmBKTx1, a new BKCa1 channel blocker from the Chinese scorpion Buthus martensi Karsch. Biochemistry 43(13): 3764-3771.

34. Imperial JS, Bansal PS, Alewood PF, Daly NL, Craik DJ, et al. (2006) A novel conotoxin inhibitor of Hv1.6 channel and nAChR subtypes defines a new superfamily of conotoxins. Biochemistry 45(27): 83318340 .

35. Lange A, Giller K, Horning S, Martin Eauclaire MF, Pongs O, Beckers $S$, et al. (2006) Toxin induced conformational changes in a potassium channel revealed by solid state NMR. Nature 440(7086): 959-962.

36. Lippens G, Najib J, Wodak SJ, Tastas A (1995) NMR sequential assignment and solution structure of chlorotoxin, a small scorpion toxin that blocks chloride channels. Biochemistry 34(1): 13-21.

37. De-Bin JA, Strichartz GR (1991) Chloride channel inhibition by the venom of scorpion Lieurus quinquestriatus. Toxicon 29(11): 14031408.

38. Valdes JJ, Thompson RG, Wolff VL, Menking DE, Rael ED, et al. (1989) Inhibition of calcium channel dihydropyridine receptor binding by purified Mojave toxin. Neurotoxicol Teratol 11(2): 129-133.

39. Moore EL, Haspel G, Libersat F, Adams ME (2006) Parasitoid wasp sting: a cocktail of GABA, taurine and beta alanine opens chloride channels for central synaptic blocks and transient paralysis of cockroach host. Neurobiol 66(8): 811-820.

40. Satitmanwiwat S, Changsangfa C, Khanuengthong A, Promthep K, Roytrakul S, et al. (2016) The scorpion venom peptide BmKn2 induces apoptosis in cancerous but not in normal human oral cells. Biomed Pharmacother 84: 1042-1050.

41. Al-Asmari AK, Ullah Z, Al Balowi A, Islam M (2017) In vitro determination of the efficacy of scorpion venoms as anti-cancer agents against colorectal cancer cells: a nano-liposomal delivery approach. Int J Nanomedicine 12:559-574. 


\section{Current Trends in Biomedical Engineering \& Biosciences}

42. Leite NB, Aufderhorst-Roberts A, Palma MS, Connell SD, Ruggiero Neto J, et al. (2015) PE and PS Lipids Synergistically Enhance Membrane Poration by a Peptide with Anticancer Properties. Biophys J 109(5): 936-947.

43. Jridi I, Catacchio I, Majdoub H, Shahbazzadeh D, El Ayeb M, et al. (2017) The small subunit of Hemilipin2, a new heterodimeric phospholipase A2 from Hemiscorpius lepturus scorpion venom, mediates the antiangiogenic effect of the whole protein. Toxicon 126: 38-46.

44. Damianoglou A, Rodger A, Pridmore C, Dafforn TR, Mosely JA, et al. (2010) The synergistic action of melittin and phospholipase A2 with lipid membranes: Development of linear dichroism for membraneinsertion kinetics. Protein Pept Lett 17(11): 1351-1362.

45. Fernandez J, Soriano V, Mayorga L, Mayor M (2005) Natural history of Hymenoptera venom allergy in Eastern Spain. Clin Exp Allergy 35(2): 179-185.

46. Fennel JF, Shipman WH, Cole LJ (1968) Antibacterial action of melittin a polypeptide from bee venom. Proc Soc Exp Biol Med 127(3): 707710.

47. Mishima S, Ono Y, Araki Y, Akao Y, Nozawa Y (2005) Two related cinnamic Acid derivatives from Brazilian honeybee propolis, baccharin and drupannin, induce growth inhibition in allografted sarcoma S-180 in mice. Biol Pharm Bull 28(6): 1025-1030.

48. Liu Z, Yang GZ, Chi CW, Wu XF (2002) Cloning and high- level expression of scorpion toxic BmKITal in Escherichia coli and insect cells. Protein Pept Lett 9(5): 419-426.

49. Hancock RE. Peptide antibiotics. Lancet 349(9049): 418- 422.

50. Hancock RE, Scott MG (2000) The role of antimicrobial peptides in animal defenses. Proc Nati Acade Sci USA 97(16): 8856- 8861.

51. Rekka E, Kourounakis L, Kourounakis P (1990) Antioxidant activity of and interleukin production affected by honey bee venom. Arzneimittelforschung 40(8): 912-913.

52. Ladokhin AS, White SH (1999) Folding of amphipathic alpha-helices on membranes: Energetics of helix formation by melittin. J Mol Biol 285(4): 1363-1369.

53. Fukushima N, Kohno M, Kato T, Kawamoto S, Okuda K, et al. (1998) Melittin, a metabostatic peptide inhibiting Gs activity. Peptides 19(5): 811-819.

54. Katoh N (2002) Inhibition by melittin of phosphorylation by protein kinase C of annexin I from cow mammary gland. J Vet Med Sci 64(9): 779-783.

55. Gerst JE, Salomon Y (1987) Inhibition by melittin and fluphenazine of melanotropin receptor function and adenylate cyclase in M2R melanoma cell membranes. Endocrinology 121(5): 1766-1772.

56. Vitale N, Thierse D, Bader MF (2010) Melittin promotes exocytosis in neuroendocrine cells through the activation of phospholipase A2. Regul Pept 165(1): 111-116.

57. Hait WN, Grais L, Benz C, Cadman EC (1985) Inhibition of growth of leukemic cells by inhibitors of calmodulin: Phenothiazines and melittin. Cancer Chemother Pharmacol 14(3): 202-205.

58. Fadeel B, Gleiss B, Hogstrand K, Chandra J, Wiedmer T, et al. (1999) Phosphatidylserine exposure during apoptosis is a cell-type-specific event and does not correlate with plasma membrane phospholipid scramblase expression. Biochem Biophys Res Commun 266(2): 504511.

59. Song CC, Lu X, Cheng BB, Du J, Li B, et al. (2007) Effects of melittin on growth and angiogenesis of human hepatocellular carcinoma BEL7402 cell xenografts in nude mice. Ai Zheng 26(12): 1315-1322.

60. Liu S, Yu M, He Y, Xiao L, Wang F, et al. (2008) Melittin prevents liver cancer cell metastasis through inhibition of the Rac1-dependent pathway. Hepatology 47(6): 1964-1973.
61. Shin JM, Jeong YJ, Cho HJ, Park KK, Chung IK, et al. (2013) Melittin suppresses HIF-1alpha/VEGF expression through inhibition of ERK and mTOR/p70S6K pathway in human cervical carcinoma cells. PLoS One 8(7): e69380.

62. Huh JE, Kang JW, Nam D, Baek YH, Choi DY, et al. (2012) Melittin suppresses VEGF-A-induced tumor growth by blocking VEGFR-2 and the COX-2-mediated MAPK signaling pathway. J Nat Prod 75(11): 1922-1929.

63. Yang X, Zhu H, Ge Y, Liu J, Cai J, et al. (2014) Melittin enhances radiosensitivity of hypoxic head and neck squamous cell carcinoma by suppressing HIF-1alpha. Tumour Biol 35(10): 10443-10448.

64. Dunn RD, Weston KM, Longhurst TJ, Lilley GG, Rivett DE, et al. (1996) Antigen binding and cytotoxicproperties of a recombinantimmunotoxin incorporating the lytic peptide, melittin. Immunotechnology 2(3): 229-240.

65. Zhao X, Yu Z, Dai W, Yao Z, Zhou W, et al. (2011) Construction and characterization of an anti-asialoglycoprotein receptor single-chain variable-fragment-targeted melittin. Biotechnol Appl Biochem 58(6): 405-411.

66. Jin H, Li C, Li D, Cai M, Li Z, et al. (2013) Construction and characterization of a CTLA-4-targeted scFv-melittin fusion protein as a potential immunosuppressive agent for organ transplant. Cell Biochem Biophys 67(3): 1067-1074.

67. Holle L, Song W, Holle E, Wei Y, Wagner T, et al. (2003) A matrix metalloproteinase 2 cleavable melittin/avidin conjugate specifically targets tumor cells in vitro and in vivo. Int J Oncol 22(1): 93-98.

68. Yang L, Cui F, Shi K, Cun D, Wang R (2009) Design of high payload PLGA nanoparticles containing melittin/sodium dodecyl sulfate complex by the hydrophobic ion-pairing technique. Drug Dev Ind Pharm 35(8): 959-968.

69. Hu H, Chen D, Liu Y, Deng Y, Yang S, et al. Target ability and therapy efficacy of immunoliposomes using a humanized antihepatoma disulfide-stabilized Fv fragment on tumor cells. J Pharm Sci 95(1): 192-199.

70. Barrajon-Catalan E, Menendez-Gutierrez MP, Falco A, Carrato A, Saceda M, et al. (2010) Selective death of human breast cancer cells by lytic immunoliposomes: Correlation with their HER2 expression level. Cancer Lett 290(2): 192-203.

71. Popplewell JF, Swann MJ, Freeman NJ, McDonnell C, Ford RC (2006) Quantifying the effects of melittin on liposomes. Biochim Biophys Acta 1768(1): 13-20.

72. Huang C, Jin H, Qian Y, Qi S, Luo H, et al. (2013) Hybrid melittin cytolyticpeptide-driven ultrasmall lipid nanoparticles block melanoma growth in vivo. ACS Nano 7(7): 5791-5800.

73. Luo Q Zhang Z, Huang C (2013) Polypeptide carrying melittin, nanoparticle carrying melittin and use thereof.

74. Zhang Z, Cao W, Jin H, Lovell JF, Yang M, et al. (2009) Biomimetic nanocarrier for direct cytosolic drug delivery. Angew Chem Int Ed Engl 48(48): 9171-9175.

75. Park D, Jung JW, Lee MO, Lee SY, Kim B, et al. (2014) Functional characterization of naturally occurring melittin peptide isoforms in two honey bee species, Apis mellifera and Apis cerana. Peptides 53: 185-193.

76. Pérez-Payá E, Dufourcq J, Braco L, Abad C (1997) Structural characterisation of the natural membrane-bound state of melittin: a fluorescence study of a dansylated analogue. Biochim Biophys Acta 1329(2): 223-236.

77. Pooga M, Hallbrink M, Zorko M, Langel U (1998) Cell penetration by transportan. FASEB J 12(1): 67-77.

78. Pfeiffer DR, Gudz TI, Novgorodov SA, Erdahl WL (1995) The peptide mastoparan is a potent facilitator of the mitochondrial permeability transition. J Biol Chem 270(9): 4923-4932. 
79. Higashijima T, Uzu S, Nakajima T, Ross EM (1988) Mastoparan, a peptide toxin from wasp venom, mimics receptors by activating GTPbinding regulatory proteins (G proteins). J Biol Chem 263(14): 64916494.

80. Mousli M, Bueb JL, Bronner C, Rouot B, Landry Y (1990) G protein activation: a receptor-independent mode of action for cationic amphiphilic neuropeptides and venom peptides. Trends Pharmacol Sci 11(9): 358-362.

81. Katsu T, Kuroko M, Morikawa T, Sanchika K, Yamanaka H, et al. (1990) Interaction of wasp venom mastoparan with biomembranes. Biochim Biophys Acta 1027(2): 185-190.

82. Nakahata N, Abe MT, Matsuoka I, Nakanishi H (1990) Mastoparan inhibits phosphoinositide hydrolysis via pertussis toxin-insensitive G-protein in human astrocytoma cells. FEBS Lett 260(1): 91-94.

83. Ozaki Y, Matsumoto Y, Yatomi Y, Higashihara M, Kariya T, et al. (1990) Mastoparan, a wasp venom, activates platelets via pertussis toxinsensitive GTP-binding proteins. Biochem Biophys Res Commun 170(2): 779-785.

84. Weingarten R, Ransnas L, Mueller H, Sklar LA, Bokoch GM (1990) Mastoparan interacts with the carboxyl terminus of the alpha subunit of Gi. J Biol Chem 265(19): 11044-11049.

85. Rocha T, de Souza BM, Palma MS, da Cruz-Hofling MA (2007) Myotoxic effects of mastoparan from Polybia paulista (Hymenoptera, Epiponini) wasp venom in mice skeletal muscle. Toxicon 50(5): 589-599.

86. Dongol T, Dhananjaya BL, Shrestha RK, Aryal G (2014) Pharmacological and immunological properties of wasp venom. In: Joghi S, Gowder T (Eds.), Pharmacology and Therapeutics; Intech: Rijeka, Croatia. pp. $47-$ 81.

87. de Azevedo RA, Figueiredo CR, Ferreira AK, Matsuo AL, Massaoka $\mathrm{MH}$, et al. (2015) Mastoparan induces apoptosis in B16F10-Nex2 melanoma cells via the intrinsic mitochondrial pathway and displays antitumor activity in vivo. Peptides 68: 113-119.

88. Yamamoto T, Ito M, Kageyama K, Kuwahara K, Yamashita K, et al. (2014) Mastoparan peptide causes mitochondrial permeability transition not by interacting with specific membrane proteins but by interacting with the phospholipid phase. FEBS J 281(17): 3933-3944.

89. Kauzmann W (1959) Some factors in the interpretation of protein denaturation. Advances in Protein Chemistry 14: 1-63.

90. Charton M, Charton BI (1982) The structural dependence of amino acid hydrophobicity parameters. J Theor Biol 99(4): 629-644.

91. Lockett MR, Lange H, Breiten B, Heroux A, Sherman W, et al. (2013) The binding of benzoarylsulfonamide ligands to human carbonic anhydrase is insensitive to formal fluorination of the ligand. Angew Chem Int Ed Engl 52(30): 7714-7717.

92. Breiten B, Lockett MR, Sherman W, Fujita S, Al-Sayah M, et al. (2013) Water networks contribute to enthalpy/entropy compensation in protein-ligand binding. J. Am. Chem. Soc. 2013; 135 (41): 1557915584.

93. Pace CN, Shirley BA, McNutt M, Gajiwala K (1996) Forces contributing to the conformational stability of proteins. FASEB J 10(1): 75-83.

94. Compiani M, Capriotti E (2013) Computational and theoretical methods for protein folding (PDF). Biochemistry 52(48): 8601-8624.

95. Callaway David J (1994) Solvent-induced organization: a physical model of folding myoglobin. Proteins 20(1): 124-138.

96. Rose GD, Fleming PJ, Banavar JR, Maritan A (2006) A backbone-based theory of protein folding. Proc Natl Acad Sci USA 103 (45): 1662316633.

97. Gerald Karp (2009) Cell and Molecular Biology: Concepts and Experiments. John Wiley and Sons, USA. pp. 128.
98. Uggerhøj LE, Poulsen TJ, Frimodt-Møller N, Wimmer R, Nyberg NT, et al. (2013) Synthetic analogs of anoplin show improved antimicrobial activities. J Pept Sci 19(11): 669-675.

99. Nakamura T, Takahashi H, Takeuchi K, Kohno T, Wakamatsu K, et al. (2005) Direct determination of a membrane-peptide interface using the nuclear magnetic resonance cross-saturation method. Biophys J 89(6): 4051-4055.

100. Monoi N, Usui M, Takahashi S, Ito H, Kumakura K, et al. (2004) Tetrapeptides on $\mathrm{N}$ - and $\mathrm{C}$-terminal regions of mastoparan inhibit catecholamine release from chromaffin cells by blocking nicotinic acetylcholine receptor. Cell Mol Neurobiol 24(1): 37-50.

101. Wakamatsu K, Okada A, Miyazawa T, Ohya M, Higashijima T (1992) Membrane-bound conformation of mastoparan-X, a G-proteinactivating peptide. Biochemistry 31(24): 5654-5660.

102. Leite NB, da Costa LC, Dos Santos Alvares D, Dos Santos Cabrera MP, de Souza BM, et al. (2011) The effect of acidic residues and amphipathicity on the lytic activities of mastoparan peptides studied by fluorescence and CD spectroscopy. Amino Acids 40(1): 91-100.

103. Mukai H, Suzuki Y, Kiso Y, Munekata E (2008) Elucidation of structural requirements of mastoparan for mast cell activation-toward the comprehensive prediction of cryptides acting on mast cells. Protein Pept Lett 15(9): 931-937.

104. Irazazabal LN, Porto WF, Ribeiro SM, Casale S, Humblot V, et al. (2016) Selective amino acid substitution reduces cytotoxicity of the antimicrobial peptide mastoparan. Biochim Biophys Acta 1858(11): 2699-2708.

105. Dal Peraro M, van der Goot FG (2016) Pore-forming toxins: Ancient, but never really out of fashion. Nat Rev Microbiol 14(2): 77-92.

106. Gilbert RJ, Dalla Serra M, Froelich CJ, Wallace MI, Anderluh G (2014) Membrane pore formation at protein-lipid interfaces. Trends Biochem Sci 39(11): 510-516.

107. Gutman Y, Lazarovici P (1997) Toxins and Signal Transduction. Harwood Academic Publishers, Netherlands. pp. 211-232.

108. Berube BJ, Bubeck Wardenburg J (2013) Staphylococcus aureus alpha-toxin: Nearly a century of intrigue. Toxins 5(6): 1140-1166.

109. Bhakdi S, Tranum-Jensen J (1987) Damage to mammalian cells by proteins that form transmembrane pores. Rev Physiol Biochem Pharmacol 107: 147-223.

110. Persechini A, Kretsinger RH (1988) Toward a model of the calmodulin-myosin light-chain kinase complex: implications for calmodulin function. J Cardiovasc Pharmacol 12(Suppl 5): S1-12.

111. Balsinde J, Winstead MV, Dennis EA (2002) Phospholipase A(2) regulation of arachidonic acid mobilization. FEBS Lett 531(1): 2-6.

112. Ramanadham S, Ali T, Ashley JW, Bone RN, Hancock WD, et al. (2015) Calcium-independent phospholipases A2 and their roles in biological processes and diseases. J Lipid Res 56(9): 1643-1668.

113. Bernard D, Vindrieux D (2014) PLA2R1: Expression and function in cancer. Biochim Biophys Acta 1846(1): 40-44.

114. Nicolas JP, Lin Y, Lambeau G, Ghomashchi F, Lazdunski M, et al. (1997) Localization of structural elements of bee venom phospholipase A2 involved in N-type receptor binding and neurotoxicity. J Biol Chem 272(11): 7173-7181.

115. Vadas P, Pruzanski W (1986) Role of secretory phospholipases A2 in the pathobiology of disease. Lab Investig 55(4): 391-404.

116. Prado M, Solano-Trejos G, Lomonte B (2010) Acute physiopathological effects of honeybee (Apis mellifera) envenoming by subcutaneous route in a mouse model. Toxicon 56(6): 1007-1017.

117. Schulz J, Gluskin AH (1991) Rethinking clinical endodontic diagnosis. J Calif Dent Assoc 19(5): 15-22. 
118. Palm NW, Rosenstein RK, Yu S, Schenten DD, Florsheim E, et al. (2013) Bee venom phospholipase A2 induces a primary type 2 response that is dependent on the receptor ST2 and confers protective immunity. Immunity 39(5): 976-985.

119. Vernon LP, Bell JD (1992) Membrane structure, toxins and phospholipase A2 activity. Pharmacol Ther 54(3): 269-295.

120. Yue HY, Fujita T, Kumamoto E (2005) Phospholipase A2 activation by melittin enhances spontaneous glutamatergic excitatory transmission in rat substantia gelatinosa neurons. Neuroscience 135(2): 485-495.

121. Lee G, Bae H (2016) Bee Venom Phospholipase A2: Yesterday's Enemy Becomes Today's Friend. Toxins (Basel) 8(2): 48.

122. Jones RG, Corteling RL, Bhogal G, Landon J (1999) A novel fab-based antivenom for the treatment of mass bee attacks. Am. J Trop Med Hyg 61(3): 361-366.

123. Liu P, Davis P, Liu H, Krishnan TR (1999) Evaluation of cytotoxicity and absorption enhancing effects of melittin-A novel absorption enhancer. Eur J Pharm Biopharm 48(1): 85-87.

124. Quintero-Hernandez V, Jimenez-Vargas JM, Gurrola GB, Valdivia HH, Possani LD (2013) Scorpion venom components that affect ionchannels function. Toxicon 76: 328-342.

125. Rowan EG, Harvey AL (2011) Snake toxins from mamba venoms: Unique tools for the physiologist. Acta Chim Slovenica 58(4): 689692.

126. Wulff H, Castle NA, Pardo LA (2009) Voltage-gated potassium channels as therapeutic targets. Nat Rev Drug Discov 8(12): 982-100.

127. Teisseyre A, Gasiorowska J, Michalak K (2015) Voltage-gated potassium channels kv1.3-potentially new molecular target in cancer diagnostics and therapy. Adv Clin Exp Med 24(3): 517-524.

128. Morales-Lazaro SL, Hernandez-Garcia E, Serrano-Flores B, Rosenbaum T (2015) Organic toxins as tools to understand ion channel mechanisms and structure. Curr Top Med Chem 15(7): 581603.

129. Alexander SP, Catterall WA, Kelly E, Marrion N, Peters JA, et al. (2015) The concise guide to pharmacology 2015/16: Voltage-gated ion channels. Br J Pharmacol 172(24): 5904-5941.

130. Alexander SP, Kelly E, Marrion N, Peters JA, Benson HE, et al. (2015) The concise guide to pharmacology 2015/16: Other ion channels. Br J Pharmacol 172(24): 5942-5955.

131. Armstrong JS (2006) Mitochondria: a target for cancer therapy. Br J Pharmacol 147(3): 239-248.

132. Kong GM, Tao WH, Diao YL, Fang PH, Wang JJ, et al. (2016) Melittin induces human gastric cancer cell apoptosis via activation of mitochondrial pathway. World J Gastroenterol 22(11): 3186-3195.

133. Jung SY, Lee KW, Choi SM, Yang EJ () Bee Venom Protects against Rotenone-Induced Cell Death in NSC34 Motor Neuron Cells. Toxins (Basel) 7(9): 3715-3726.

134. Lee J, Lee DG (2014) Melittin triggers apoptosis in Candida albicans through the reactive oxygen species-mediated mitochondria/ caspase-dependent pathway. FEMS Microbiol Lett 355(1): 36-42.

135. Jones S, Howl J (2012) Enantiomer-specific bioactivities of peptidomimetic analogues of mastoparan and mitoparan: Characterization of inverso mastoparan as a highly efficient cell penetrating peptide. Bioconjug Chem 23(1): 47-56.

136. Sharma G, Modgil A, Zhong T, Sun C, Singh J (2014) Influence of short-chain cell-penetrating peptides on transport of Doxorubicin encapsulating receptor-targeted liposomes across brain endothelial barrier. Pharm Res 31(5): 1194-1209.

137. Pooga M, Hallbrink M, Zorko M, Langel U (1998) Cell penetration by transportan. FASEB J 12(1): 67-77.

138. Wierzbicki PM, Kogut M, Ruczynski J, Siedlecka-Kroplewska K, Kaszubowska L, et al. (2014) Protein and siRNA delivery by transportan and transportan 10 into colorectal cancer cell lines. Folia Histochem Cytobiol 52(4): 270-280.

139. Fanghanel S, Wadhwani P, Strandberg E, Verdurmen WP, Burck J, et al (2014) Structure analysis and conformational transitions of the cell penetrating peptide transportan 10 in the membrane-bound state PLoS One 9(6): e99653.

140. Pooga M, Kut C, Kihlmark M, Hallbrink M, Fernaeus S, et al. (2001) Cellular translocation of proteins by transportan. FASEB J 15(8): 1451-1453.

141. Oller-Salvia B, Teixido M, Giralt E (2013) From venoms to BBB shuttles: Synthesis and blood-brain barrier transport assessment of apamin and a nontoxic analog. Biopolymers 100(6): 675-686.

142. Wooddell CI, Rozema DB, Hossbach M, John M, Hamilton HL, et al. ( Hepatocyte-targeted RNAi therapeutics for the treatment of chronic hepatitis B virus infection. Mol Ther 21(5): 973-985

143. Moreno M, Zurita E, Giralt E (2014) Delivering wasp venom for cancer therapy. J Control Release 182: 13-21.

144. Zhu LN, Fu CY, Zhang SF, Chen W, Jin YT, et al. (2013) Novel cytotoxic exhibition mode of antimicrobial peptide anoplin in MEL cells, the cell line of murine Friend leukemia virus-induced leukemic cells. J Pept Sci 19(9): 566-574.

145. Zhang W, Li J, Liu LW, Wang KR, Song JJ, et al. (2010) A novel analog of antimicrobial peptide Polybia-MPI, with thioamide bond substitution, exhibits increased therapeutic efficacy against cancer and diminished toxicity in mice. Peptides 31(10): 1832-1838.

146. Wang K, Yan J, Liu X, Zhang J, Chen R, et al. (2011) Novel cytotoxity exhibition mode of polybia-CP, a novel antimicrobial peptide from the venom of the social wasp Polybia paulista. Toxicology 288(13): 27-33.

147. Wang KR, Zhang BZ, Zhang W, Yan JX, Li J, et al. (2008) Antitumor effects, cell selectivity and structure-activity relationship of a novel antimicrobial peptide polybia-MPI. Peptides 29(6):963-968.

148. Bhavya J, Francois NN, More VS, More SS (2016) Scorpion Toxin Polyptides as Therapeutic Agents: An Overview. Protein Pept Lett 23(9): 848-859.

149. Ding J, Chua PJ, Bay BH, Gopalakrishnakone P (2014) Scorpion venoms as a potential source of novel cancer therapeutic compounds. Exp Biol Med (Maywood) 239(4): 387-393.

150. Carbone E, Wanke E, Prestipino G, Possani LD, Macklicke A (1982) Selective blockage of voltage-dependent $\mathrm{K}+$ channels by a novel scorpion toxin. Nature 296(5852): 90-91.

151. Rochat H, Berrard P, Couraud F (1979) Scorpion toxins: Chemistry and mode of action. Adv Cytopharmacol 3: 325-334.

152. Zlotkin E, Eistan M, Bindokas VP, Adams ME, Moyer M, et al. (1991) Functional duality and structural uniqeness of depressant insect selective neuritoxins. Biochemistry 30(19): 4814-4821.

153. Zlotkin E, Maskowitz H, Herrmann R, Pelhate M, Gordon D (1995) Insect sodium channel as the target for insect selective neurotoxins from scorpion venom. molecular action of insecticides on ion channels 58-85.

154. Miller C, Moczydlowski E, Lotore R, Phillips M (1985) Charybdofoxin, a protein inhibitor of single $\mathrm{Ca}++$ activated $\mathrm{K}+$ channels from mammalion skeltal muscle. Nature 313(6000): 316-318.

155. Delepierre M, Prochnicka A, Possani LD (1997) A novel potassium ion channel-blocking toxin from the scorpion Pandinus imperator: A1HNMR analysis using a nano-NMR probe. Biochemistry 36(9): 2649-2658 
156. DeBin JA, Maggio JE, Strichartz GR (1993) Purification and charcteriztion of cholorotoxin, a chloride channel ligand from the venom of the scorpion. Am J Physiol 264(pt 2): C361-369.

157. Possani LD, Becerril B, Delepierre M, Tytgat J (1999) Scorpion toxins specific for Na+ channels. Eur J Biochem 264(2): 287-300.

158. Béchohra L, Laraba-Djebari F, Hammoudi-Triki D (2016) Cytotoxic activity of Androctonus australis hector venom and its toxic fractions on human lung cancer cell line. J Venom Anim Toxins Incl Trop Dis 22: 29.

159. Beceril B, Marangoni S, Possani LD (1997) Toxicon and geses isolated from the scorpion of the genus Tityus Arevier. Toxicon 35(6): 821835.

160. Tytgat J, Chandy KG, Garrcia ML, Gutman GA, Martin-Eaculaire MF, et al. (1999) A unified nomenclature for short chain peptides isolated from scorpion venoms: alpha-KTx molecular subfamilies. Trends Pharmacol Sci 20(11): 444 -447.

161. Mu Q Lin G, Patton VK, Wang K, Press OW, et al. (2016) Gemcitabine and Chlorotoxin Conjugated Iron Oxide Nanoparticles for Glioblastoma Therapy. J Mater Chem B Mater Biol Med 4(1): 32-36.

162. Mu Q Jeon M, Hsiao MH, Patton VK, Wang K, et al. (2015) Stable and efficient Paclitaxel nanoparticles for targeted glioblastoma therapy. Adv Healthc Mater 4(8): 1236-1245.

163. Du Q, Hou X, Wang L, Zhang Y, Xi X, et al. (2015) AaeAP1 and AaeAP2: novel antimicrobial peptides from the venom of the scorpion, Androctonus aeneas: structural characterization, molecular cloning of biosynthetic precursor-encoding cDNAs and engineering of analogues with enhanced antimicrobial and anticancer activities. Toxins (Basel) 7(2): 219-237.

164. Ortiz E, Gurrola GB, Schwartz EF, Possani LD (2015) Scorpion venom components as potential candidates for drug development. Toxicon 93: $125-135$.

165. Costa PM, Cardoso AL, Custódia C, Cunha P, Pereira de Almeida L, et al. (2015) MiRNA-21 silencing mediated by tumor-targeted nanoparticles combined with sunitinib: A new multimodal gene therapy approach for glioblastoma. J Control Release 207: 31-39.

166. Wang H, Gu W, Xiao N, Ye L, Xu Q (2014) Chlorotoxin-conjugated graphene oxide for targeted delivery of an anticancer drug. Int Nanomedicine 9: 1433-1442.

167. Aroui S, Dardevet L, Najlaoui F, Kammoun M, Laajimi A, et al. (2016) PTEN-regulated AKT/FoxO3a/Bim signaling contributes to Human cell glioblastoma apoptosis by platinum-maurocalcin conjugate. Int J Biochem Cell Biol 77(Pt A): 15-22.

168. Aroui S, Dardevet L, Ben Ajmia W, de Boisvilliers M, Perrin F, et al (2015) A Novel Platinum-Maurocalcine Conjugate Induces Apoptosis of Human Glioblastoma Cells by Acting through the ROS-ERK/ AKT-p53 Pathway. Mol Pharm 12(12): 4336-4348.

169. Xu T, Fan Z, Li W, Dietel B, Wu Y, et al. (2016) Identification of two nove Chlorotoxin derivatives CA4 and CTX-23 with chemotherapeutic and anti-angiogenic potential. Sci Rep 6: 19799.

170. Ojeda PG, Henriques ST, Pan Y, Nicolazzo JA, Craik DJ, et al. (2017) Lysine to arginine mutagenesis of chlorotoxin enhances its cellular uptake. Biopolymers 108(5).

171. Zhao L, Zhu J, Cheng Y, Xiong Z, Tang Y, et al. (2015) ChlorotoxinConjugated Multifunctional Dendrimers Labeled with Radionuclide 131I for Single Photon Emission Computed Tomography Imaging and Radiotherapy of Gliomas. ACS Appl Mater Interfaces 7(35): 19798-808.

172. Cohen-Inbar O, Zaaroor M (2016) Glioblastoma multiforme targeted therapy: The Chlorotoxin story. J Clin Neurosci 33: 52-58.
173. Wang X, Guo Z (2015) Anti-gliomas Effect of Chlorotoxin-Conjugated Onconase at High Dose. Cell Biochem Biophys 73(2): 389-392.

174. Valdez-Velazquéz LL, Romero-Gutierrez MT, Delgado-Enciso I, Dobrovinskaya O, Melnikov V, et al. (2016) Comprehensive analysis of venom from the scorpion Centruroides tecomanus reveals compounds with antimicrobial, cytotoxic, and insecticidal activities. Toxicon 118: 95-103.

175. Locatelli E, Naddaka M, Uboldi C, Loudos G, Fragogeorgi E, et al (2014) Targeted delivery of silver nanoparticles and alisertib: in vitro and in vivo synergistic effect against glioblastoma. Nanomedicine 9(6): 839-849.

176. Guo G, Cui Y, Chen H, Zhang L, Zhao M, et al. (2016) Analgesicantitumor peptide inhibits the migration and invasion of HepG2 cells by an upregulated VGSC $\beta 1$ subunit. Tumour Biol 37(3): 3033-3041.

177. Misra SK, Ye M, Kim S, Pan D (2014) Highly efficient anti-cancer therapy using scorpion 'NanoVenin'. Chem Commun 50(87): 132201323.

178. Zhao QQ Zhang WD, Wu LC, Zhang LL, Wang ZP, et al. (2015) [Mechanism of Polypeptide Extract from Scorpion Venom Combined Rapamycin in Enhancing Autophagy of H22 Hepatoma Cells: an Experimental Study]. Zhongguo Zhong Xi Yi Jie He Za Zhi 35(7): 866870.

179. Sui WW, Zhang WD, Wu LC, Zhang YY, Wang ZP, et al. (2014) Study on the mechanism of polypeptide extract from scorpion venom on inhibition of angiogenesis of H 22 hepatoma. Zhongguo Zhong Xi Yi Jie He Za Zhi 34(5): 581-586.

180. Wang X, Wu G, Lu C, Zhao W, Wang Y, et al. (2012) A novel delivery system of doxorubicin with high load and $\mathrm{pH}$-responsive release from the nanoparticles of poly $(\alpha, \beta$-aspartic acid) derivative. Eur Pharm Sci 47(1): 256-264.

181. Zheng AH, Zhang WD, Wang ZP, Wang ZX, Wu LC, et al. (2013) Research on the effect and mechanism of polypeptide extract from scorpion venom combined with 5-fluorouracil on vasculogenic mimicry of H22 hepatoma. Zhongguo Zhong Xi Yi Jie He Za Zhi 33(4): 492-496.

182. Guo X, Ma C, Du Q, Wei R, Wang L, et al. (2013) Two peptides, TsAP1 and TsAP-2, from the venom of the Brazilian yellow scorpion, Tityus serrulatus: evaluation of their antimicrobial and anticancer activities. Biochimie 95(9): 1784-1794.

183. Ning YN, Zhang WD, Wu LC (2012) Study on the mechanism of polypeptide extract from scorpion venom to promote the restraint of cyclophosphamide on Lewis lung cancer. Zhongguo Zhong Xi Yi Jie He Za Zhi 32(4): 537-542.

184. Graf N, Mokhtari TE, Papayannopoulos IA, Lippard SJ (2012) Platinum(IV)-chlorotoxin (CTX) conjugates for targeting cancer cells. J Inorg Biochem 110: 58-63.

185. Tong-ngam P, Roytrakul S, Sritanaudomchai H (2015) BmKn-2 scorpion venom peptide for killing oral cancer cells by apoptosis. Asian Pac J Cancer Prev 16(7): 2807-2811.

186. Li W, Li Y, Zhao Y, Yuan J, Mao W (2014) Inhibition effects of scorpion venom extracts (Buthus matensii Karsch) on the growth of human breast cancer MCF-7 cells. Afr J Tradit Complement Altern Med 11(5): 105-110

187. Yoo B, Ifediba MA, Ghosh S, Medarova Z, Moore A (2014) Combination treatment with theranostic nanoparticles for glioblastoma sensitization to TMZ. Mol Imaging Biol 16(5): 680-689.

188. Safdar S, Payne CA, Tu NH, Taite LJ (2012) Targeted nitric oxide delivery preferentially induces glioma cell chemosensitivity via altered p53 and $\mathrm{O}(6)$-methylguanine-DNA methyltransferase activity. Biotechnology and Bioengineering 110(4): 1211-1220. 
This work is licensed under Creative Commons Attribution 4.0 License

DOI: 10.19080/CTBEB.2018.16.555945
Your next submission with Juniper Publishers will reach you the below assets

- Quality Editorial service

- Swift Peer Review

- Reprints availability

- E-prints Service

- Manuscript Podcast for convenient understanding

- Global attainment for your research

- Manuscript accessibility in different formats ( Pdf, E-pub, Full Text, Audio)

- Unceasing customer service

Track the below URL for one-step submission https://juniperpublishers.com/online-submission.php 